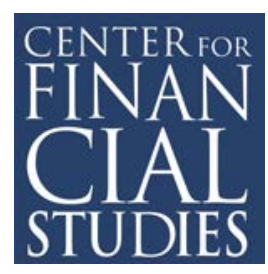

CFS Working PAPER

No. $2013 / 27$

\title{
Market Implied Costs of Bankruptcy
}

Johann Reindl, Neal Stoughton, Josef Zechner 


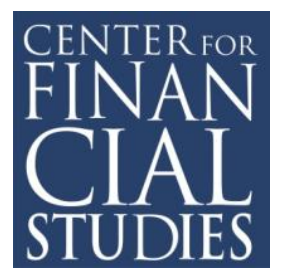

\section{CFS Working Paper Series}

The Center for Financial Studies, located in Goethe University's House of Finance in Frankfurt, is an independent non-profit research center, funded by the non-profit- making organisation Gesellschaft für Kapitalmarktforschung e.V. (GfK). The CFS is financed by donations and by contributions of the GfK members, as well as by national and international research grants. The GfK members comprise major players in Ger- many's financial industry. Established in 1967 and closely affiliated with the University of Frankfurt, it provides a strong link between the financial community and academia. CFS is also a contributor to policy debates and policy analyses, building upon relevant findings in its research areas.

The CFS Working Paper Series presents the result of scientific research on selected topics in the field of money, banking and finance. The authors were either participants in the Center's Research Fellow Program or members of one of the Center's Research Projects.

If you would like to know more about the Center for Financial Studies, please let us know of your interest.

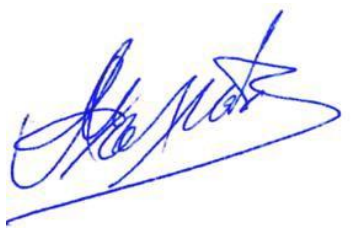

Prof. Michalis Haliassos, Ph.D.
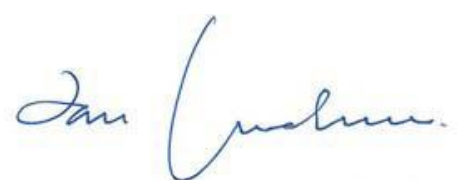

Prof. Dr. Jan Pieter Krahnen

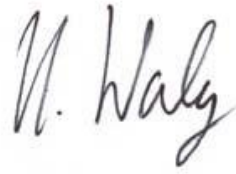

Prof. Dr. Uwe Walz 


\title{
Market Implied Costs of Bankruptcy
}

\author{
Johann Reindl \\ BI Norwegian Business School \\ Neal Stoughton \\ WU-Vienna University of Economics and Business \\ Josef Zechner \\ WU-Vienna University of Economics and Business
}

August 2013

\begin{abstract}
This paper takes a novel approach to estimating bankruptcy costs by inference from market prices of equity and put options using a dynamic structural model of capital structure. This approach avoids the selection bias of looking at firms in or near default and therefore permits theories of ex ante capital structure determination to be tested. We identify significant cross sectional variation in bankruptcy costs across industries and relate these to specific firm characteristics. We find that asset volatility and growth options have significant positive impacts, while tangibility and size have negative impacts. Our bankruptcy cost variable estimate significantly negatively impacts leverage ratios. This negative impact is in addition to that of other firm characteristics such as asset intangibility and asset volatility. The results provide strong support for the tradeoff theory of capital structure.
\end{abstract}

\section{Introduction}

Bankruptcy costs, that is the loss in value that occurs when ownership of a firm is transferred from equityholders to debtholders, are one of the two key determinants in the tradeoff theory of capital structure, which has been at the forefront of finance research over the last 50 years. According to the theory, these costs are to be weighed against the advantage of interest deductibility of corporate debt. Of course, obtaining precise estimates of these key parameters is crucial in determining the validity of the theory. While a lot of progress has been made with respect to estimating the corporate tax advantage of debt, the magnitude and cross-sectional distribution of bankruptcy costs have remained challenges to researchers.

\footnotetext{
*This paper has been presented at the University of Hong Kong, HKUST, the Goethe University Frankfurt the Frankfurt School of Management, the University of Zürich, the European Finance Association, the European Winter Finance Conference and the IDC Rothschild Ceasarea Conference. We appreciate the helpful comments of Rudiger Frey, Jean-Charles Rochet and Toni Whited, members of the seminar audiences and discussants Patrick Bolton, Egor Matveyev and Martin Schmalz.
} 
One approach to obtain estimates is by directly using samples of firms that have gone bankrupt. This procedure has several main difficulties. First, it is almost impossible to get precise data on the magnitude of costs such as legal costs for all involved parties in large samples. Second, one would need to have a complete list of all costs incurred in bankruptcy, both direct as well as indirect. This is a formidable task. For example, some bankruptcy components will be borne by third parties, such as employees. Other bankruptcy costs may represent opportunity costs, such as foregone profitable projects. Third, there is a crucial selection bias. One would expect that bankruptcy costs and the probability of bankruptcy would be negatively correlated which therefore implies that, relying only on bankrupt firms gives a biased ex-ante estimate. This would result in understating the true bankruptcy costs.

An alternative to directly measuring these costs is to use market prices of debt instruments to infer them. This, however, is complicated by the lack of clean market prices for corporate debt. Also, debt has frequently a very opaque structure with significant heterogeneity due to contractual differences. Furthermore, large components of corporate liabilities, e.g. bank debt, are usually not traded at all. All of these criticisms apply to credit default swaps (CDS) as well, with the further complication that a CDS only applies to a single reference entity. It would be difficult to pick the appropriate reference entity ex ante. Finally it is well known that counterparty risk is a concern with respect to the use of CDS prices.

The cleanest set of market prices that could potentially be used to extract bankruptcy costs, are those related to a firm's equity. This approach is frustrated by the fact that, without further refinancing, the costs of bankruptcy are not reflected in equity prices, since they are not borne by equityholders ex post. However, in a more realistic situation, where firms face continued refinancing needs, equity prices will reflect bankruptcy costs, even in the absence of any new equity issues. To see this, consider a firm that wishes to roll over its maturing debt by issuing new debt with the same face value and the same coupon rate. Of course the market value of the new debt will in general not equal the required redemption payment to the old debtholders. If the difference is positive, it can be paid out to equityholders as a dividend; if negative, it must be financed via a reduced dividend or a new share issue. Under this scenario, bankruptcy costs are reflected in the market value of the new debt and therefore in the net distribution to the equityholders. Since the ex-ante equity price reflects future debt refinancings, it therefore must incorporate bankruptcy costs.

This is the essence of our approach. We use a structural model of continuous debt refinancing, due to Leland (1994) and Leland (1998) to back out bankruptcy costs from equity securities. We do not rely solely on common equity prices but augment our estimation procedure through the observation of equity put option prices. Out-of-the-money put prices are very sensitive to bankruptcy states and afford a considerable improvement in accuracy over relying solely on common stock prices. In doing so, the paper derives put option prices for this structural model of debt refinancing. As a byproduct of the estimation procedure, we also obtain time-series estimates of underlying unlevered asset prices which not only include assets in place, but growth opportunities as well. Our bankruptcy cost estimates are at the upper end of the range of 
previously estimated averages but they reflect considerable cross-sectional variation by industry. This paper is the first to examine the extent and implications of this heterogeneity.

We believe our paper makes important methodological and empirical contributions. Our methodology uses stock prices and put options to back out bankruptcy costs and other structural parameters, such as bankruptcy thresholds, distance to default and hidden debt. Using put options is crucial since stock prices alone do not provide enough sensitivity to underlying structural parameters. The method is applied to estimate bankruptcy costs during the financial crisis period 2008 to 2010. In this period, there was considerable variation of put option prices and volatility that facilitates robust estimation of bankruptcy costs. Many firms were pushed to higher risks of default during this period.

Our estimates are reasonable and exhibit considerable industry variation. First of all, we find that bankruptcy costs are strongly and positively related to distance to default over the relevant range. We relate these bankruptcy cost estimates to firm characteristics. We find that bankruptcy costs are strongly positively related to the underlying asset volatility, and negatively to firm size and asset tangibility. We find that market to book ratios increase bankruptcy costs significantly, which provides strong support for the hypothesis that growth options are lost in bankruptcy.

Second, we explore the determinants of leverage ratios via a cross-sectional analysis. When we include our estimates of bankruptcy costs we improve the explanatory power in the cross-section considerably over the previous literature. Our direct measure of bankruptcy costs is negatively related to leverage, which provides considerable support for the tradeoff theory of capital structure. Also, the asset volatility estimates show up strongly in the cross-sectional relationship as having a negative effect on leverage. We find that market to book ratios have further eplanatory power for leverage in addition to that already accounted for by bankruptcy cost estimates.

Third, our method is also extended to provide estimates of hidden liabilities, which are either off the balance sheet, or difficult to measure, such as health care liabilities or employee labor legacy contracts. We find considerable cross-sectional variation here as well.

The literature on bankruptcy costs has a long history. One important approach looks at direct costs of firms that have gone bankrupt. Weiss (1990) evaluates 37 Chapter 11 bankruptcies between 1980 and 1986 and finds direct costs of bankruptcy average $3.1 \%$ of the book value of debt plus the market value of equity. Ang et al. (1982) report bankruptcy costs of 7.5\% of total liquidation value of assets for 86 liquidations between 1963 and 1979. However, for small firms bankruptcy fees might wipe out 100\% of the assets. Bris et al. (2006) consider 300 cases of mostly smaller nonpublic firms between 1995-2001. They find that in 68\% of Chapter 7 cases, the bankruptcy fees exceeded the entire estate.

A series of papers have also attempted to measure indirect bankruptcy costs. One difficulty lies in distinguishing actual distress costs from the economic factors ultimately responsible for pushing the firm into 
difficulty. Altman (1984) deals with this by comparing expected profits to actual profits for the 3 years prior to bankruptcy. He finds an average cost of $10 \%$ of firm value measured just prior to bankruptcy. Combined direct and indirect costs average $16.7 \%$ of firm value for this sample. Andrade \& Kaplan (1998) consider 31 firms that have become financially distressed after a management buyout or a leveraged recapitalization between 1980 and 1989 but were not economically distressed. They find costs of financial distress between $10 \%$ and $20 \%$ of firm value. These estimates are used by Almeida \& Philippon (2007) to calculate the exante value of distress costs by multiplying them by the risk neutral default probabilities obtained from CDS spreads. These ex ante estimates amount to an average of 4.5\%. Elkamhi et al. (2012) point out that estimates by Andrade \& Kaplan (1998) should be applied to ex-post asset values at the time of bankruptcy. They therefore extend this approach using a structural model, which allows them to map the ex-post bankruptcy cost percentages to ex-ante percentages and find that they are too low to support commonly observed leverage ratios. Nevertheless they still rely on the original estimates by Andrade \& Kaplan (1998).

Korteweg (2010) uses market prices of debt and equity of firms close to bankruptcy to estimate bankruptcy costs from the net-benefits to leverage. This is based on the presumption that firms close to bankruptcy have lost all the tax benefits of debt and the net-benefits to leverage reflect bankruptcy costs alone. The author finds bankruptcy costs amount to 15 to 30\%. Davydenko et al. (2012) back out distress costs from market value changes upon the announcement of default. Assuming that investors do not fully anticipate default, distress costs can be estimated from the change in the market value of the firm upon announcement. They find average costs of distress of $21 \%$, lower costs of $20.2 \%$ for highly-levered firms and higher costs for investment-grade firms (28.8\%). Once again, these estimates may be biased since severely distressed firms are likely to be the ones with low bankruptcy costs.

As has been recognized (Glover, 2011), using estimates of incurred bankruptcy costs from defaulted firms can potentially bias estimates downwards as one might expect that firms with lower bankruptcy costs are more likely to run the risks of going into default. Glover (2011) uses simulated method of moments to estimate the parameters of a structural model in a general equilibrium setting with macro variables estimated over the business cycle. The model is embedded in a dynamic capital structure setting that assumes the firm trades off tax advantages with bankruptcy costs. The author finds average distress costs of $45 \%$ of firm value which compare to $25 \%$ for a sample of defaulted firms. Our model, by contrast, adopts a more parsimonious approach, which does not rely on the tradeoff theory for capital structure to hold for firms in the sample.

The paper proceeds as follows. Section 2 contains the structural model. Section 3 documents the estimation procedure and describes the data. Our main results are reported in Section 4 with respect to bankruptcy costs estimates and our cross-sectional analysis of leverage ratios. Section 5 contains robustness tests showing that our results are also reasonable in the context of a simulated sample. Section 6 concludes. Some of the technical results are contained in an appendix. 


\section{Structural Model}

In contrast to other approaches that rely on the prices of debt securities or CDS our approach relies on the use of market prices of equity and equity derivatives. This approach has several advantages. First, many debt securities are not traded at all. Second, even if they are traded, they are often illiquid and characterized by high bid-ask spreads. Also their prices depend on asset specific features, such as covenants and seniority. Third, bankruptcy may be triggered by liabilities other than debt, such as defined benefit pension plans, for which market prices do not exist. By contrast, equity is a residual claim and therefore its price is affected by bankruptcy, independently of the interactions between different liability categories.

While equity is clearly affected by the probability of bankruptcy, it is less clear how it is affected by bankruptcy costs, since equityholders usually do not bear these costs ex post. However, in a dynamic model of capital structure changes over time, where firms must roll over debt, bankruptcy costs do affect equity values since they impact the price at which new debt can be issued. We therefore rely on a parsimonious dynamic capital structure model in which firms must continuously refinance a constant fraction of their debt in order to keep book values constant.

More specifically, we consider the debt of a firm to consist of a continuum of maturities, from zero to infinity. In any instant of time, a fraction $m$ of the outstanding face value of total debt, $B$, is retired. Thus, the face value of the original debt that remains at time $t$ is equal to $e^{-m t} B$. At any point in time, the expiring debt is replaced by a new issue with face value $m B$ of equal seniority. This new issue consists again of a continuum of maturities, matching the original profile of the debt before refinancing. Thus, the total face value of debt, $B$, remains constant over time with an average maturity of $M=1 / m$. This stationary capital structure policy has been used in Leland (1994) and Leland (1998). In this environment, the firm's aggregate coupon payment per unit of time is denoted by $C$ and is assumed constant over time. Thus, total payments to all debt holders (debt replacement plus coupon) per unit of time, $d t$, are given by $(C+m B) d t$.르

The equityholders control whether the firm enters bankruptcy or not, which is modeled as a first passage stopping time when the unlevered asset value strikes the default barrier. In general equity holders are willing to continue to pay the interest costs in return for receiving cash flows from earnings and refinancings, until the unlevered value is sufficiently low. Although our model does not include accumulated cash holdings explicitly, we theorize that cash will not impact the default barrier significantly as it will be optimal for equity holders to use up cash first before hitting the barrier (otherwise the cash will just transfer to the debtholders without benefit to equity).

\footnotetext{
${ }^{1}$ Alternative capital structure dynamics with finite maturity debt can be found in Leland \& Toft (1996) and, with endogenous roll-over decisions, in Dangl \& Zechner (2007).

${ }^{2}$ Although we do not include issuance costs in our formal model, the model could potentially be extended easily in this direction. Specifically one could add a small proportional cost in the case of negative dividends (where the equityholders are increasing capital). Also debt issuance costs could be treated as an outflow that is proportional to the face value of new debt issues.
} 
The firm is assumed to generate earnings before interest and taxes, EBIT, that follows a geometric Brownian motion with drift $\hat{\mu}$ under the risk neutral measure, $Q$. Therefore, after-tax earnings of an all-equity firm, $X_{t}$, is given by $X_{t}=(1-\tau) E B I T$, with $Q$-dynamics given by

$$
d X_{t}=\hat{\mu} X_{t} d t+\sigma X_{t} d W_{t}
$$

We define the value of unlevered assets, $A_{t}$, as the present value of future after-tax earnings:

$$
\begin{aligned}
A_{t} & \equiv E^{Q}\left[\int_{s=t}^{\infty} e^{-r s} X_{s} d s\right] \\
& =\frac{X_{t}}{r-\hat{\mu}}
\end{aligned}
$$

Let $\delta=\frac{X_{t}}{A_{t}}=r-\hat{\mu}$ denote the earnings yield on the unlevered asset value. Thus, the dynamics of $A$ under the risk neutral measure satisifies

$$
d A_{t}=(r-\delta) A_{t} d t+\sigma A_{t} d W_{t}
$$

We now derive the value of the levered firm, $V_{t}$. As in the standard tradeoff theory, the value of $V_{t}$ is the sum of the unlevered asset value plus the present value of tax-shields minus the present value of bankruptcy costs. Let $G\left(t, A_{t}\right)$ be the price at time $t$ of an Arrow-Debreu security that pays one dollar at the time of bankruptcy, $T_{B}$, when the unlevered asset value is $A_{B}$. Using risk-neutral valuation, the price of this security at time $t$ is

$$
\begin{aligned}
G\left(t, A_{t}\right) & \equiv E^{Q}\left[e^{-r T_{B}}\right] \\
& =\left(\frac{A_{t}}{A_{B}}\right)^{-\eta(r)}
\end{aligned}
$$

where

$$
\begin{aligned}
\eta(r) & =\frac{\mu_{B}+\sqrt{\mu_{B}^{2}+2 r \sigma^{2}}}{\sigma^{2}} \\
\mu_{B} & =r-\delta-\frac{\sigma^{2}}{2}
\end{aligned}
$$

Therefore the levered firm value at time $t$ is given by

$$
V\left(A_{t}\right)=A_{t}+\frac{\tau C}{r}\left[1-G\left(t, A_{t}\right)\right]-\alpha A_{B} G\left(t, A_{t}\right)
$$

where the second term is the present value of the tax shield reflecting states in which the firm does not go bankrupt. The third term represents the present value of bankruptcy costs, assuming that costs are a proportion $\alpha$ of the value of the unlevered assets at the time of default, $A_{B}$. We do not explicitly allow for 
financial distress costs affecting equityholders prior to default. Nevertheless our model is consistent with a case in which these costs are accumulated and incurred at the time of bankruptcy. Since the present value of such costs impacts the price at which new debt can be issued, these costs therefore impact equityholders before bankruptcy when they refinance a proportion of the existing debt. In this sense our bankruptcy cost estimate also captures distress costs borne by equityholders prior to default. Our model is also applicable to

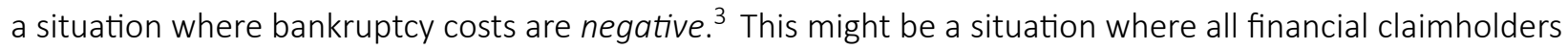
are better off in bankruptcy because of the ability to extinguish a non-financial liability.

As shown by Leland (1994), if equity holders default optimally the default boundary would be determined by the smooth pasting condition as:

$$
A_{B}^{*}=\frac{\frac{c+m B}{r+m} \eta(z)-\frac{\tau C}{r} \eta(r)}{1+(1-\alpha) \eta(z)+\alpha \eta(r)},
$$

where $z=r+m$. Intuitively, note that a negative bankruptcy cost, $\alpha<0$ implies that equity holders will default later, since $\eta(z)>\eta(r)$.

\subsection{Valuing Corporate Securities}

We now use the above pricing equations to derive the values of corporate securities and derivatives thereof. We begin with the value of corporate debt outstanding at time $t$. Its value is the present value of the cash flows to debtholders if no default happens plus the value of bankruptcy costs incurred at default. Because of the redemption schedule of debt, for every dollar of face value at time $t$, there will be $e^{-m\left(T_{B}-t\right)}$ dollars of the original face value outstanding at the time of bankruptcy. The time $t$ price of an Arrow Debreu claim that pays exactly one dollar at time $t$ if the debt claim remains outstanding at the time of bankruptcy is given by

$$
G^{z}\left(t, A_{t}\right)=\left(\frac{A_{t}}{A_{B}}\right)^{-\eta(z)} .
$$

Moreover the market value of existing debt at time $t$ is given by

$$
D\left(A_{t}\right)=\frac{C+m B}{z}\left[1-G^{z}\left(t, A_{t}\right)\right]+(1-\alpha) A_{B} G^{z}\left(t, A_{t}\right) .
$$

Since the value of equity, $S\left(A_{t}\right)$, is the difference between the value of the levered firm and the value of debt, we get

$$
S\left(A_{t}\right)=V\left(A_{t}\right)-D\left(A_{t}\right)
$$

To see how bankruptcy costs enter the equity price, recall that $\alpha A_{B}$ are the ex-post bankruptcy costs in the event of default. The present value of these costs is given by $\alpha A_{B} G\left(t, A_{t}\right)$. Since the share of these costs

\footnotetext{
${ }^{3}$ Indeed we identify a negative bankruptcy cost for a small number of firms in our sample.
} 
borne by existing debtholders is $\alpha A_{B} G^{z}\left(t, A_{t}\right)$, it follows that the remaining amount, $\alpha A_{B}\left[G\left(t, A_{t}\right)-G^{z}\left(t, A_{t}\right)\right]$, is embedded in the equity price $S_{t}$.

In order to identify the parameters of the underlying structural model, we rely on equity as well as put prices, since the latter are even more sensitive than equity itself to bankruptcy probabilities and the costs of bankruptcy. Puts derive their value from states where the stock price is below the strike price, and that includes all the bankruptcy states. In contrast to equity, put prices are increasing with the likelihood of bankruptcy. Thus, using both equity and put options simultaneously, can lead to more reliable estimates. Furthermore, exchange-traded puts are standardized and thus counterparty risk and illiquidity are not an issue.

In this framework put options are compound options, since equity itself is already a call option on the asset value. In addition a put option on a levered firm has features similar to a barrier/knock-out option because the firm can default before the option expires. To derive a put pricing formula, we split the put payoff at maturity, $P_{T}$, into a part that is paid out if the firm has not defaulted and a part paid in case the firm has defaulted $\mathbb{\text { H: }}$

$$
P_{T}=\left(K-S\left(A_{T}\right)\right)^{+} 1_{T_{B}>T}+K 1_{T_{B} \leq T}
$$

The put payoff (8) formula reveals the compound nature of the option since the equity value at maturity, $S\left(A_{T}\right)$, is itself a function of the underlying firm value. In order to derive the price of the option at time $t$, we first define $A^{*}$ as the time- $T$ asset value for which the option is at the money $\left(S\left(A^{*}\right)=K\right)$. The put price can be derived as the discounted expected value of the strike price over asset paths in which the firm goes bankrupt prior to expiration plus the discounted expected value of $K-S$ in states where the firm does not go bankrupt prior to expiration and $A_{T} \leq A^{*}$. Hence the put price is equal to the following expectation under the risk neutral measure, $Q$.

$$
P_{t}=e^{-r(T-t)} E^{Q}\left[\left(K-S\left(A_{T}\right)\right) 1_{A_{T} \leq A^{*} \wedge T_{B}>T}\right]+K e^{-r(T-t)} E^{Q}\left[1_{T_{B} \leq T}\right]
$$

In the appendix, we derive the following expression for the put price by substituting the stock price into the above formula and taking expectations. We employ several changes of measure to simplify the notation. The put has a positive value at expiry either when the firm goes bankrupt or when the option expires in the money but the firm has not gone bankrupt. In the former case, the stock price is zero, so the stock price does not enter the put pricing equation. However in the latter case it does. Define the set of sample paths for which the option is in the money and the firm does not default until maturity of the option as $Y_{T}=\left\{\left(A_{t}\right)_{t \in[0, T]}: A_{T} \leq A^{*}, T_{B}>T\right\}$. Let $1_{Y_{T}}$ be the indicator function equal to one in the event states $Y_{T}$.

\footnotetext{
${ }^{4}$ To obtain an analytical solution, we assume the options are European and neglect the price difference to the American variety. For instance, Bakshi et al. (2003) find that the difference between the American option implied volatility and the European option implied volatility is within the bid-ask spread.
} 
The put pricing formula involves taking expectations, $E\left(1_{Y_{T}}\right)$, with respect to three probability measures. The first is a pricing measure with respect to the unlevered asset process, denoted by $Q^{A}$, the second, $Q^{G}$, is the measure with respect to the claim whose price (under the risk neutral measure) is $G\left(t, A_{t}\right)$, and the third, $Q^{z}$ is the claim whose price (also under the risk neutral measure) is $G^{z}\left(t, A_{t}\right)$. The put pricing formula is derived in the appendix as

$$
\begin{aligned}
P_{t}= & e^{-r(T-t)} K\left(Q\left(Y_{T}\right)+Q\left(T_{B} \leq T\right)\right)-A_{t} e^{-\delta(T-t)} Q^{A}\left(Y_{T}\right) \\
& -\frac{\tau C}{r}\left(e^{-r(T-t)} Q\left(Y_{T}\right)-G\left(t, A_{t}\right) Q^{G}\left(Y_{T}\right)\right)+\alpha A_{B} G\left(t, A_{t}\right) Q^{G}\left(Y_{T}\right) \\
& +\frac{C+m B}{z}\left(e^{-r(T-t)} Q\left(Y_{T}\right)-e^{m(T-t)} G^{z}\left(t, A_{t}\right) Q^{z}\left(Y_{T}\right)\right) \\
& +(1-\alpha) A_{B} e^{m(T-t)} G^{z}\left(t, A_{t}\right) Q^{z}\left(Y_{T}\right)
\end{aligned}
$$

Equation (9) together with the equity pricing formula (7) will now be used to estimate the underlying structural parameters, including bankruptcy costs, for our sample of firms.

\section{Estimation Method}

We will use daily pricing data on equity and put options to estimate the structural parameters of the model. Complicating factors are that the pricing equations are non-linear, that prices are observed with error and the underlying asset value process is unobservable and is therefore a latent variable. We therefore use Kalman filtering techniques in the estimation method.

\subsection{Estimation of Structural Parameters and The Asset Value Process}

Since observed prices of stocks and put options will in general differ from the theoretical prices of our model, we follow common practice and add an error term to the pricing equations (7) and (9). The observed pricing errors may be due to various reasons such as microstructure effects or non-synchronous trading of options and stocks. We assume additive, normally distributed errors in the log-specification for stock $i$ :

$$
\begin{aligned}
& s_{i, t}=s\left(A_{i, t} ; \vartheta_{i}\right)+e_{i, t}^{S} \\
& p_{i, t}=p\left(A_{i, t} ; K_{i}, \vartheta_{i}\right)+e_{i, t}^{p}
\end{aligned}
$$

such that pricing errors can be interpreted as percentage deviations. $s\left(A_{i, t} ; \vartheta_{i}\right)=\log S\left(A_{i, t} ; \vartheta_{i}\right)$ where $S\left(A_{i, t} ; \vartheta_{i}\right)$ is derived from equation (7) for the stock price of firm $i$ as a function of the asset value and the model parameter vector $\vartheta_{i}$. Similarly, $p\left(A_{i, t} ; K_{i}, \vartheta_{i}\right)=\log P\left(A_{i, t} ; K_{i}, \vartheta_{i}\right)$ denotes price of the put option derived in equation (9) which depends on the asset value, the strike price, and the vector of model parameters $\vartheta_{i}$. 
Our specification requires a non-standard estimation technique, because we have both pricing errors as well as an unobservable asset value in equation (10). Hence, estimation methods, such as standard maximum likelihood as applied by Duan (1994) or Ericsson \& Reneby (2005) are not applicable. We instead employ a different method. A Kalman-filter is used to back out the unobservable asset value for each date, and model parameters and states are jointly estimated, using maximum likelihood.

For the time series regression we need to specify the dynamics of the unlevered asset value process under the physical measure. Assuming a constant market price of risk, $\lambda$, the $P$-dynamics are given by

$$
d A_{t}=\mu A_{t} d t+\sigma A_{t} d w_{t}
$$

where $\mu=r-\delta+\lambda \sigma$.

Let $a_{t}=\log A_{t}$. From Itō's lemma it follows that the the log-asset value process can be written in discrete time as

$$
a_{t}=\left(\mu-\frac{\sigma^{2}}{2}\right) \Delta t+a_{t-1}+\sigma \sqrt{\Delta t} z_{t}
$$

with $z_{t} \stackrel{i i d}{\sim} N(0,1)$. Since pricing errors may be autocorrelated, we follow Bates $(\overline{2000})$ in specifiying the following process for the errors in equation (10).

$$
\begin{aligned}
& e_{i, t}^{S}=\rho_{i, S} e_{i, t-1}^{S}+\varepsilon_{i, t}^{S} \\
& e_{i, t}^{P}=\rho_{i, P} e_{i, t-1}^{P}+\varepsilon_{i, t}^{P}
\end{aligned}
$$

The system to be estimated can be represented in state-space form with the asset value process (12) and the $A R(1)$-process (13) forming the state equation and the pricing equations (10) as the measurement equation. While the state equation is linear the measurement equation is non-linear. Therefore we employ a more general method than the standard linear Kalman filter. Specifically, we use the unscented Kalman filter 5 to deal with the non-linearity of the measurement equation. The transformation, on which the unscented Kalman filter is based, enables the calculation of unbiased estimates of the mean and covariance matrix of a transformed variable. In this case the transformed variables are the stock and put prices which are a function of the asset value. The unscented transformation captures the true mean and covariance matrix of the prices accurately to the third order, assuming as we have in our model that $A_{t}$ is a geometric Brownian motion. A detailed description of the unscented Kalman filter applied to our problem is given in appendix B.

\footnotetext{
${ }^{5}$ See Wan \& Van Der Merwe (2001) for a comprehensive derivation and Carr \& Wu (2010) for an application to continuous-time finance-models.
} 


\subsection{Data}

We use daily equity and put prices from May 2008 to September 2010 which were obtained from Datastream. The necessary accounting data are from WorldScope. Our initial sample consists of all constituent firms in the S\&P500 as of December 2007. Although these are relatively large firms, two firms in this sample did in fact file for chapter 11 bankruptcy protection within the estimation period: GM on June 1, 2009 and CIT Group on November 1, 2009. Both firms were included in our estimation procedure. We require the firms to have at least 50 data points with a complete set of variables (stock and put option prices, as well as accounting variables) available. For every date, we use the closing stock price plus one put option. We require the options to satisfy a minimum trading criterion. Specifically, we require the option to fall in the 50th-percentile of the most traded options during that day. In addition the option prices must satisfy the basic intrinsic value condition and, if several options are used, relative arbitrage bounds must hold. As a consequence, the option price series to be fitted consists of a series of different put options with changing maturities and strike prices. We thus expect the model to fit option prices less well than stock prices.

\subsubsection{Parameters to be estimated}

Our structural model assumes that the principal amount of debt outstanding as well as the coupon rate, the tax rate and the average debt maturity is constant. In reality, firms do change their capital structures and, in fact, several restructuring events are observed for many of the firms in our sample. We therefore use the most recent balance sheet value of total liabilities, which is available at quarterly frequency, as the representation of the book value of debt outstanding. With the book value of debt changing over time, it is consistent that also the coupon, the debt maturity, the default barrier and the tax shield change over time. To account for this, we assume that the coupon and the tax shield are affine functions of the latest book value of debt. Furthermore, in this case, from equation (5), it can be shown that the default boundary, $A_{B}$, is also an affine function of the book value of debt. To allow for the possibility that default is not chosen freely by equity holders ex post, but instead is influenced by debt covenants, off balance sheet liabilities and other financial frictions, we estimate the affine parameter directly. We assume that the firm may default earlier than ex post optimal for equity holders and therefore allow the firm to default at the maximum between the estimated boundary and the optimal boundary. This method captures some ability to precommit by equityholders. We also use a lower bound for the estimated boundary equal to one-half of the optimal boundary. Finally, the average debt maturity is inferred from the latest balance sheet data on the proportion of long and short term debt. 8 In order to derive the average maturity of total liabilities, we start by calculating a weighted average

\footnotetext{
${ }^{6}$ Since put options with different strikes behave similarly with respect to changes in the asset value and in the other model parameters, very little would be gained by using more than one option in the estimation.

${ }^{7} \mathrm{~A}$ similar assumption is employed in Ericsson et al. (2007) and Elkamhi et al. (2012).

${ }^{8}$ While a typical firm usually has several different kinds of debt outstanding our capital structure model considers only a single bond. We treat all of them as a single debt issue. Consequently, the coupon rate and the maturity of debt have to be interpreted as
} 
of a long-term maturity, standardized to be five years, and a short-term maturity, standardized to one year, where the weights are given by the fraction of long and short-term debt divided by total liabilities. Then, we estimate the average maturity as an affine function of this weighted average of standard maturities.

Table 1 summarizes our estimation assumptions for the capital structure variables.

Table 1: Capital Structure Parameter Estimates

\begin{tabular}{lll} 
variable & model & estimation specification \\
\hline Debt book value & $B$ & Balance sheet value of total liabilities \\
Coupon & $C$ & $\lambda_{C} B$ \\
Tax shield & $\tau C$ & $\lambda_{T} B$ \\
Default barrier & $A_{B}$ & $\max \left(\lambda_{B} B, \frac{1}{2} A_{B}^{*}\right)$ \\
Average maturity & $m$ & $\lambda_{m} M$ where $M=\frac{\text { longterm Debt }}{\text { total Debt }} * 5+\left(1-\frac{\text { longterm Debt }}{\text { total Debt }}\right) * 1$
\end{tabular}

In total there are twelve parameters to be estimated for each firm using the stock and put prices. Therefore the estimated parameter vector can be described as $\vartheta=\left(\mu, \delta, \sigma^{2}, \lambda_{B}, \lambda_{C}, \lambda_{\tau}, \lambda_{m}, \alpha, \sigma_{S}, \sigma_{P}, \rho_{S}, \rho_{P}\right)$.

\section{Results}

As mentioned before, we started with the 500 constituents of the S\&P 500 as of December, 2007. Out of this original population, we were unable to estimate the model for 116 firms since they lacked some relevant data (such as option prices or balance sheet liabilities). For 20 firms, the estimation procedure did not converge. 9 Therefore we were left with a remaining sample of 364 firms. For each firm we used the maximum likelihood procedure to estimate bankruptcy costs and underlying asset volatilities, along with their associated confidence bounds. In section 5 we performed a Monte Carlo simulation with a given bankruptcy cost and asset volatility and found that our estimation procedure results in unbiased estimates and reasonably tight confidence intervals.

To evaluate the marginal benefit of using option prices in addition to the stock prices, we attempted to estimate the parameters of the model with equity prices alone for a random subsample of the firms. In all cases, the estimation did not converge. Therefore we conclude that the use of option prices is critical for this model specification. For our sample of 364 firms we evaluated the goodness-of-fit by computing the mean absolute value of the time series errors for the two security prices. We then aggregated the mean absolute pricing errors over all firms by computing the overall distribution of pricing errors for all firms which is indicated in Figure 1. We found that the most likely absolute error range was between 1 and 2 percent for averages over the different forms of debt.

${ }^{9}$ We did not find any systematic pattern amongst these firms that would indicate that they have biased our remaining sample in any significant way. 
equity prices and between 14 and 15 percent for option prices. Thus, equity prices appear to be estimated more precisely than option prices. This can be for a number of reasons. First, trading volume is lower for options than for stocks; hence microstructure effects may be more significant for the former. Also, for the options we periodically change the option series and strike price so the option is not necessarily the same over time.

Figure 1: Model Fit. This shows the distribution of mean absolute percentage errors of the actual and fitted stock price (left side) and the actual and fitted put option price (right side)
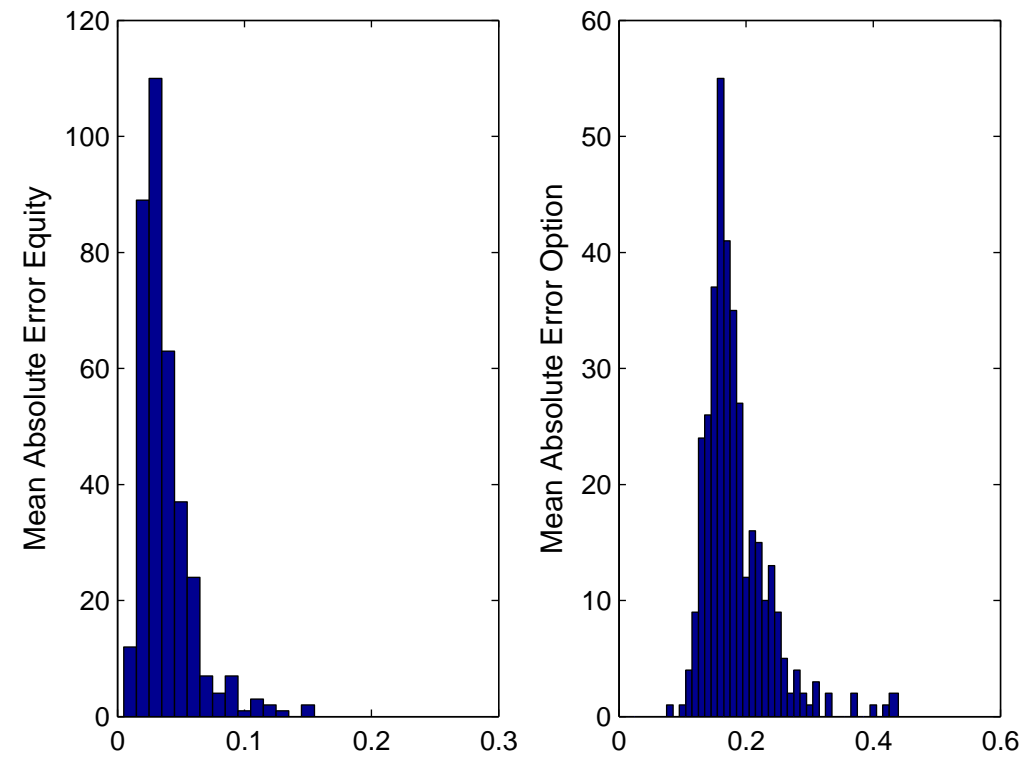

\subsection{Bankruptcy costs and firm characteristics}

Our first main finding is that implied bankruptcy costs vary quite widely in the cross-section of firms. Figure 2 illustrates the differences by industry classification.10 We display the point estimates from averages across firms in a given industry as well as the $5 \%$ confidence bounds above and below. In other words, the true industry estimate falls within the shaded bar with 95\% probability. Point estimates of costs vary from less than $10 \%$ in the case of utilities to over $60 \%$ in the coal industry. Most of the estimates are in the range of $20-30 \%$. Nevertheless there is huge cross-industry variation. We find that industries with high barriers to entry have low bankruptcy costs. Food, tobacco, mining, and the financial industry are examples. This indicates that firms in such industries may continue to operate without severe adverse impacts subsequent

\footnotetext{
${ }^{10}$ We use the Fama-French industry classifications available on http://mba.tuck.dartmouth.edu/pages/faculty/ken. french/Data_Library/det_30_ind_port.html. We have also tried other industry classifications but the results remain unaffected. Results are available from the authors upon request.
} 
to bankruptcy. Bankruptcy costs are higher for firms in services, business equipment and transportation. One potential reason for this finding is that they all rely on human capital and either explicit or implicit longterm contracts with customers. Such relationships may be irrevocably broken if the firm defaults. We look at these relations more specifically in the regression framework in section 4.2 .

Figure 2: Average Industry Distress Costs. This graph shows the percent bankruptcy costs as estimated using Fama-French industry classifications.The midpoint of the bar graph shows the point estimate and two-sided $5 \%$ confidence bounds are given by the red shaded area above and the blue shaded area below.

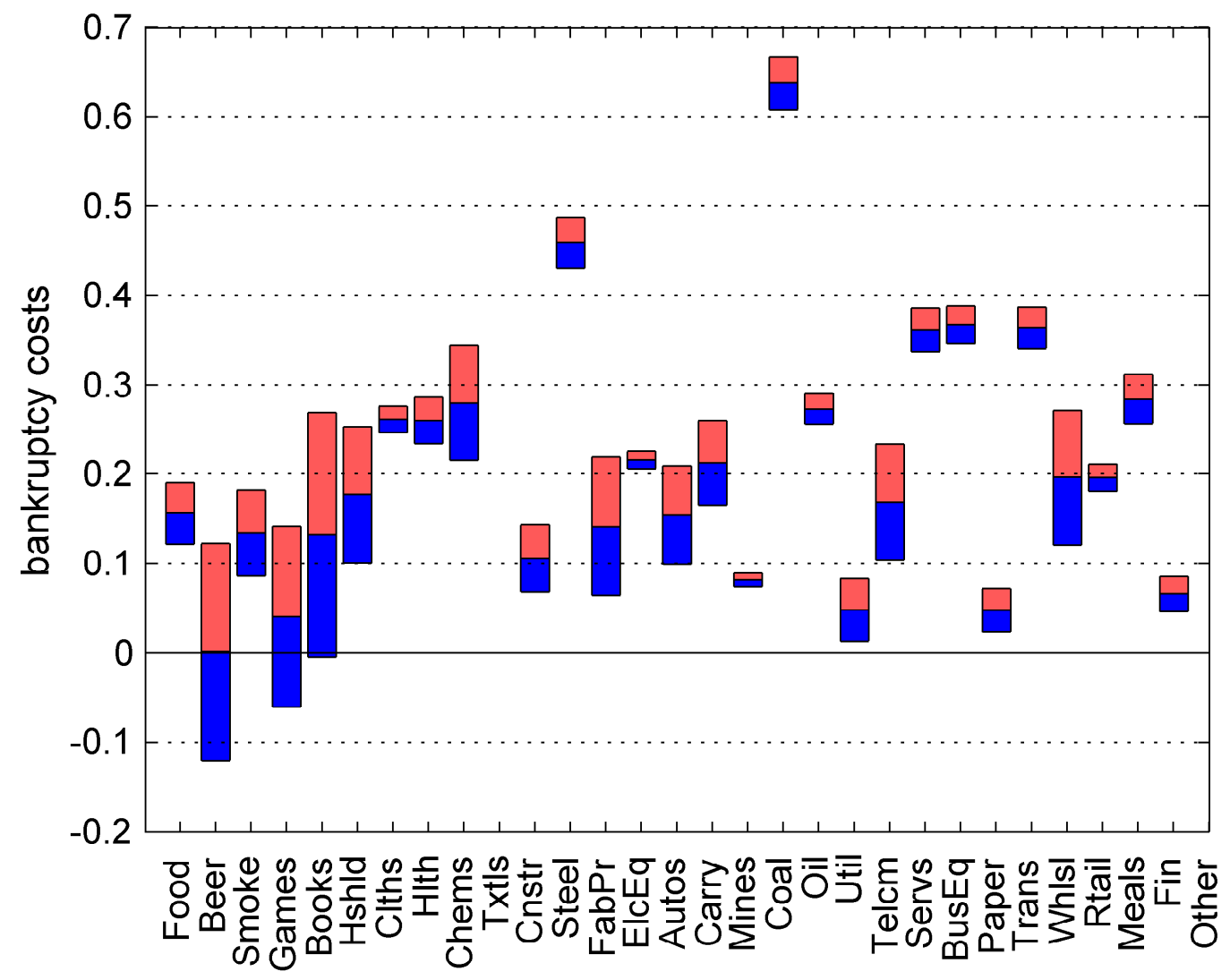

As part of our estimation procedure we derive the underlying (unlevered) asset value process, $A_{t}$. The average volatility of this process throughout our sample is displayed by industry in Figure 3. As with the previous figure, we display the point estimates for voliatiliy as well as the $5 \%$ confidence bounds. In this case, the confidence intervals are significantly tighter, indicating that our volatility estimates are, not surprisingly, more precise. We find that point estimates of unlevered asset volatilities are around the level of 0.2. We also find some cross-industry variation. Games, construction, coal and oil are among the industries with the highest volatility levels. This is intuitive. Utilities have a very low asset volatility - this also accords with expectations. 
Figure 3: Average Industry Asset Volatility. This graph shows the average asset volatility estimates by FamaFrench industry classification. The midpoint of the bar graph shows the point estimate and two-sided 5\% confidence bounds are given by the red shaded area above and the blow shaded area below.

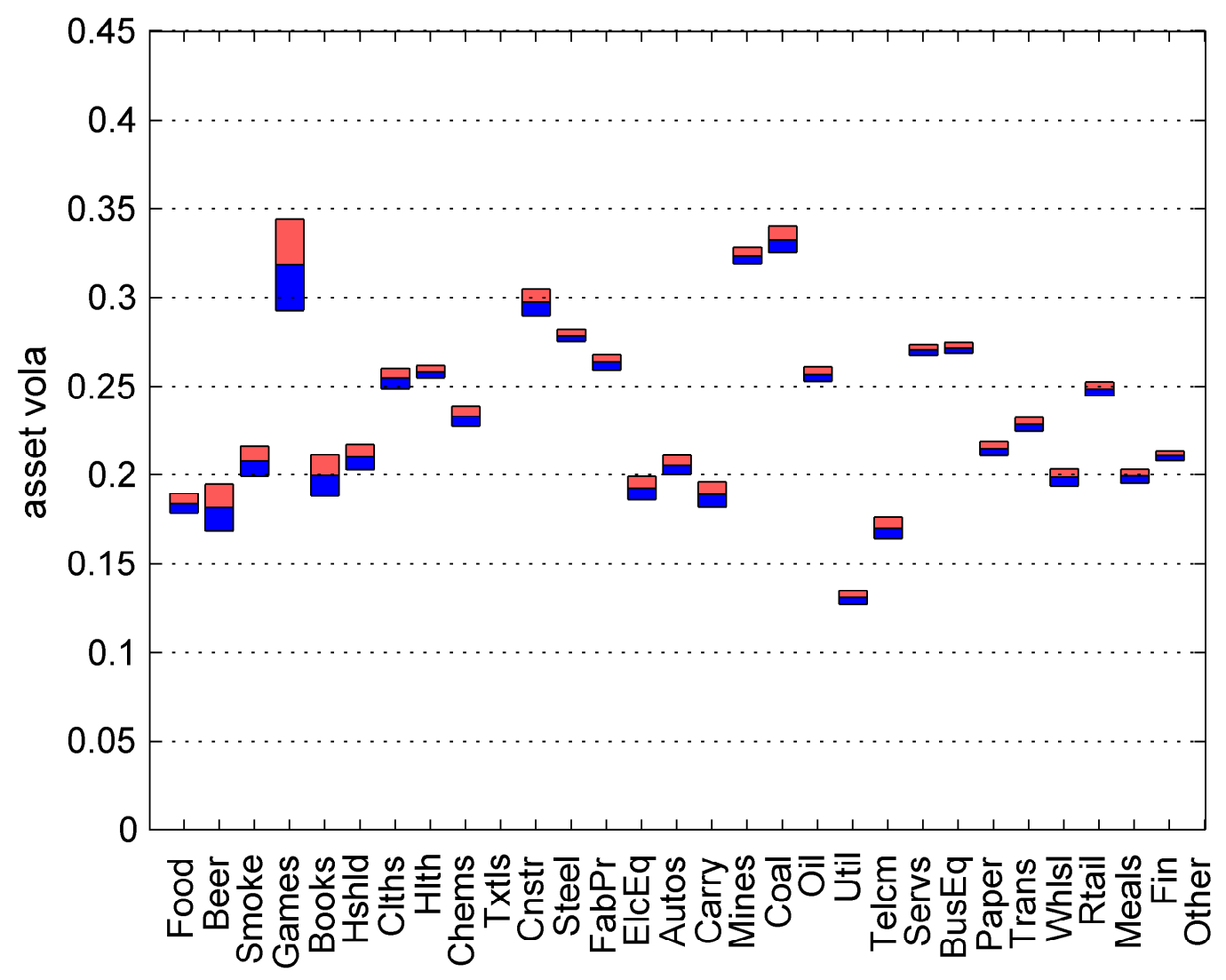


Of course, along with bankruptcy costs, the volatility estimates ought to matter for leverage choices; this is investigated more specifically later in section 4.3.

We next investigate the relationship of bankruptcy costs with respect to "distance to default". Here we use the measure originally employed by Moodys-KMV whereby we measure the distance of the underlying asset value from the bankruptcy threshold in terms of standard deviations. Using the distance to default is one form of a debt rating 11 Distance to default is defined as

$$
D T D=\frac{\ln A_{t}-\ln A_{B}}{\sigma_{A}} .
$$

We sort firms into quintiles, based on their average distances to default. Then we look for systematic variation in estimated bankruptcy costs, loss given default, leverage and asset volatility. Our results are presented in Table 2. For reference, the loss given default is defined as

$$
L G D=1-\frac{(1-\alpha) A_{B}}{B} .
$$

Table 2: Firms are sorted into 5 quintiles representing distance to default. The resulting average bankruptcy costs, LGD, leverage, and asset volatility are displayed.

\begin{tabular}{l|lllll} 
Distance to default & 2.73 & 4.20 & 5.29 & 6.40 & 8.64 \\
\hline Bankruptcy costs & 0.03 & 0.18 & 0.38 & 0.28 & 0.15 \\
LGD & 0.11 & 0.18 & 0.43 & 0.40 & 0.23 \\
Leverage & 0.73 & 0.62 & 0.56 & 0.54 & 0.55 \\
Asset volatility & 0.22 & 0.22 & 0.25 & 0.25 & 0.21 \\
$A_{B} / A_{B}^{*}$ & 1.42 & 1.42 & 0.81 & 0.72 & 0.53 \\
$A_{B} / B$ & 0.93 & 1.03 & 1.06 & 0.97 & 0.97
\end{tabular}

We find very plausibly that bankruptcy costs increase with firms' distances to default, at least up to a value of five standard deviations away from the default boundary. However, at the upper range, bankruptcy costs are decreasing somewhat. We find similar patterns for the LGD: there is a strong increase of estimated LGD with DTD over the range where firms have measurable default risks. Firms with the lowest distance to default tend to have high levels of leverage. Interestingly, asset volatilities do not vary much at all with respect to distance to default. Finally Table 2 illustrates an interesting relationship between the estimated and the optimal default threshold. Recall that the optimal default threshold is the value of the unlevered assets where equity holders would find it optimal to stop contributing capital to keep the firm going and to allow the debtholders to assume control - mathematically it is where the smooth-pasting condition holds. We find that for firms closest to default, the estimated default threshold is almost 50 percent higher than the optimal default

\footnotetext{
${ }^{11}$ We do not have data on the actual debt ratings of firms so we have not been able to use actual ratings in our analysis.
} 
threshold. This makes sense in the case where such firms have "precommitted" to default earlier through tough covenants and are thus forced into bankruptcy. However, we also find that many firms far away from bankruptcy have estimated default boundaries that are significantly below the optimal ones. At the extreme, firms more than eight standard deviations away from bankruptcy have default boundaries only 50 percent of the optimal. These cases may represent situations where equityholders desire to continue to put in capital beyond where they can expect a financial return commensurate with their outside opportunities. These may be situations where some large shareholders may enjoy additional benefits of ownership, or situations where self-interested managers are able to persuade equity holders to continue. Another explanation for this finding could be that debtholders find it in their best interest to engage in partial debt forgiveness, interest reductions or maturity extensions, etc. since this may reduce the expected bankruptcy costs borne by them.

Having considered some of the univariate estimates produced by our model, we now turn to some explanations and link this to the theoretical literature.

\subsection{Regression Results}

We now provide a linear regression analysis of the factors affecting firm bankruptcy costs, in order to better understand what the key determinants are. In doing so we utilize a cross-sectional regression framework of the following sort:

$$
\alpha_{i}=B_{0}+B_{1}^{\top} Y_{i}+F E_{i}+\varepsilon_{i}
$$

where $Y_{i}$ represents a vector of firm characteristics, and $F E_{i}$ are industry dummies. The explanatory variables chosen are from the beginning of the time series estimation period (second quarter 2008) which was used to estimate the bankruptcy costs. Some of the explanatory variables derive from our estimation results. Others are calculated from other items such as balance sheet reports. The variables are defined in Table 9 in the appendix.

We first present Table 3. This table contains regression estimates for $\alpha$ based on the smallest set of firm characteristics. In this case our sample size is reduced to 222 firms. We perform this regression for both the balance sheet asset value as well as for our estimated asset value.

In this regression we depict results for both balance sheet asset values and estimated asset values as well as with and without industry fixed effects. Since the adjusted $R^{2}$ including industry fixed effects does not increase very much, we conclude that most of the industry variations are already incorporated in the other right hand side variables. We see clearly that bankruptcy cost is strongly increasing in asset volatility. Our simulations in section 5 indicates that this relation is not the result of a spurious correlation built into our estimation procedure. This could be due to asymmetric information since higher asset volatility may reflect a less liquid market for the underlying assets. Moreover, asset volatility may result from larger growth options 
Table 3: Regressions of bankruptcy cost, $\alpha$, on the explanatory variables of asset volatility, asset size, tangibility and the pension funding gap and the market to book ratio. The regressions are performed using both the balance sheet asset value from accounting statements as well as using the estimated asset value. The balance sheet data is from Q2 2008. Regressions are also performed with and without industry fixed effects. Significance levels are indicated by *** for significance at the $1 \%$ level, ** for significance at the $5 \%$ level, and * for significance at the $10 \%$ level. Standard errors are given in parenthesis.

\begin{tabular}{ccc|cc} 
& \multicolumn{3}{c}{ Balance Sheet Asset Value } & \multicolumn{2}{c}{ Estimated } & Asset Value \\
\hline & $\alpha$ & $\alpha$ & $\alpha$ & $\alpha$ \\
\hline Constant & 0.06 & $0.37^{*}$ & 0.11 & 0.32 \\
& $(0.14)$ & $(0.20)$ & $(0.14)$ & $(0.20)$ \\
Asset Volatility & $0.52^{* *}$ & 0.43 & $0.96^{* * *}$ & $0.93^{* * *}$ \\
& $(0.26)$ & $(0.30)$ & $(0.24)$ & $(0.29)$ \\
Log Assets & -0.04 & $-0.07^{* *}$ & -0.03 & $-0.06^{*}$ \\
& $(0.03)$ & $(0.03)$ & $(0.03)$ & $(0.03)$ \\
Tangibility/Assets & 0.01 & -0.27 & $-0.42^{* * *}$ & $-0.59^{* * *}$ \\
& $(0.14)$ & $(0.17)$ & $(0.13)$ & $(0.14)$ \\
Pension Funding Gap & 0.03 & -0.01 & -0.05 & -0.09 \\
& $(0.09)$ & $(0.10)$ & $(0.09)$ & $(0.10)$ \\
MTB & $0.10^{* * *}$ & $0.10^{* * *}$ & $0.05^{* * *}$ & $0.04 * *$ \\
& $(0.02)$ & $(0.02)$ & $(0.02)$ & $(0.02)$ \\
adj $R^{2}$ & 0.24 & 0.30 & 0.26 & 0.33 \\
Ind FE & $\mathrm{N}$ & $\mathrm{Y}$ & $\mathrm{N}$ & $\mathrm{Y}$ \\
$\mathrm{N}$ & 222 & 222 & 226 & 226 \\
\hline
\end{tabular}


which may not be transferable in the event of bankruptcy, implying higher costs. We find that for two of our specifications size has a significant decreasing effect on bankruptcy costs. Recall that $\alpha$ measures proportional bankruptcy costs. Since the constant term for the regression is positive, absolute bankruptcy costs are increasing in size up to some point and decreasing thereafter. The observation that bankruptcy costs can decrease for large firms can be due to large firms having more market power, even when reorganized after bankruptcy. Also, in practice, there may be a fixed cost element in bankruptcy costs, although we have modeled bankruptcy costs as proportional. Finally there can be some aspects of tangibility that may be captured by size, e.g. brand identity. Our measure of tangibility illustrates that this also has independent explanatory power for decreasing bankruptcy costs when we use our method for estimating asset values. There is obviously a more liquid market for tangible assets, there are fewer informational asymmetries, and the liquidation value is close to book value, implying that there is less likelihood of a "fire sale" discount. This again accords with expectations. We do not find significant results for the pension funding gap as a descriptor for bankruptcy costs. However, the sign is negative which is consistent with the prediction that higher funding deficits are a benefit in bankruptcy, i.e., reduces net bankruptcy costs. Finally and importantly, the market to book ratio enters with a positive sign in terms of bankruptcy costs. This provides strong direct evidence that growth options are expected to be lost in the event of bankruptcy.

Our most complete set of regression estimates is contained in Table 4 . Using this larger set of regressors, we have a reduced sample size of only 99 firms. Note that now the adjusted $R^{2}$ actually declines with fixed effects showing that there is no inter-industry variation that is not already incorporated. We find broadly similar results with respect to the original set of regressors. While labor intensity is not significant in any of the specifications it does enter with a negative sign. This is consistent with the idea that labor costs are expected to be reduced in the event of bankruptcy. Also, R\&D/assets seems to have a negative effect on bankruptcy costs as well. This points out that not all benefits from growth opportunities are lost in the event of bankruptcy. For instance, if $R \& D / a s s e t s$ is correlated with patents and these are transferable then these assets are not reduced in value when bankruptcy occurs.

In summary we have found that bankruptcy costs increase with cash flow risk, while they decrease with firm size as well as with asset tangibility. Moreover estimated costs increase strongly with market to book ratios, indicating that overall growth options are lost in bankruptcy. Finally we find that bankruptcy costs do vary widely amongst industries as indicated by the fact that industry dummies increase the explanatory power $\left(R^{2}\right)$ significantly.

\subsection{Regression results on leverage}

We now employ a similar cross-sectional regression framework to analyze the impact of firm characteristics on observed leverage ratios, where importantly we employ our estimates for bankruptcy costs in addition to the other variables. By virtue of our firm specific bankruptcy cost estimates, our model is the first to 
Table 4: The regression of estimated bankruptcy cost, $\alpha$, for each firm on firm characteristics. The characteristic variables are defined in the text. The regression is done using both the balance sheet value for total assets as well as the estimated asset value. The regression is done with and without industry fixed effects. The balance sheet data is from Q2 2008. Significance at the $1 \%$ level is indicated by *** while significance at the $5 \%$ level is indicated with ${ }^{* *}$ and $*$ denotes significance at the $10 \%$ level. Standard errors are given in parenthesis.

\begin{tabular}{|c|c|c|c|c|}
\hline & \multicolumn{2}{|c|}{ Balance Sheet Asset Value } & \multicolumn{2}{|c|}{ Estimated Asset Value } \\
\hline & $\alpha$ & $\alpha$ & $\alpha$ & $\alpha$ \\
\hline \multirow[t]{2}{*}{ Constant } & $0.60 * *$ & $0.87 * *$ & $0.72 * * *$ & $0.87 * *$ \\
\hline & $(0.25)$ & $(0.37)$ & $(0.26)$ & (0.39) \\
\hline \multirow[t]{2}{*}{ Asset Volatility } & 0.24 & 0.19 & $0.72 *$ & 0.63 \\
\hline & $(0.39)$ & $(0.46)$ & $(0.39)$ & $(0.47)$ \\
\hline \multirow[t]{2}{*}{ Log Assets } & $-0.16 * * *$ & $-0.17 * * *$ & $-0.15 * * *$ & $-0.15^{* *}$ \\
\hline & $(0.04)$ & $(0.06)$ & $(0.05)$ & $(0.06)$ \\
\hline \multirow[t]{2}{*}{ Tangibility/Assets } & -0.05 & -0.16 & $-0.56 * *$ & $-0.66 * *$ \\
\hline & $(0.23)$ & $(0.27)$ & $(0.25)$ & $(0.30)$ \\
\hline \multirow[t]{2}{*}{ Labor Intensity } & -11.04 & $-40.23^{*}$ & -10.64 & -30.14 \\
\hline & (9.68) & $(22.55)$ & (9.94) & $(23.57)$ \\
\hline \multirow[t]{2}{*}{ R\&D/Assets } & $-4.40^{*}$ & -4.83 & -4.21 & -4.20 \\
\hline & $(2.62)$ & $(3.49)$ & $(4.22)$ & $(5.87)$ \\
\hline \multirow[t]{2}{*}{ Pension Funding Gap } & -0.02 & -0.01 & -0.04 & -0.03 \\
\hline & $(0.15)$ & (0.19) & $(0.16)$ & $(0.19)$ \\
\hline \multirow[t]{2}{*}{ MTB } & $0.12^{* * *}$ & $0.12^{* * *}$ & $0.07 * *$ & 0.06 \\
\hline & $(0.04)$ & $(0.04)$ & $(0.03)$ & $(0.04)$ \\
\hline $\operatorname{adj} R^{2}$ & 0.29 & 0.26 & 0.25 & 0.22 \\
\hline Ind FE & $N$ & Y & $N$ & Y \\
\hline $\mathrm{N}$ & 99 & 99 & 100 & 100 \\
\hline
\end{tabular}


actually include bankruptcy cost directly in a true cross sectional framework. Existing studies of leverage determinants either ignore bankruptcy costs or have had to resort to conjectured proxies.

We also include firm profit as another explanatory variable, as there is substantial evidence in the literature that it affects leverage. Finally the market to book ratio is also included. Profitability and market to book are defined in the appendix.

Before discussing the regression results we also define three leverage ratios, based on common approaches in the literature. The first measure is defined as market leverage (ML), which is the ratio of the market value of debt and the market value of the levered firm using our estimation approach for both. We also employ quasi market leverage ( $\mathrm{QML}$ ) which is the book value of debt divided by the sum of the book value of debt plus the market value of equity. This approach therefore assumes that the book value of debt is equal to its market value. The final leverage measure is standard book leverage (BL), the ratio of book debt to total assets at book.

The leverage estimation is given as:

$$
l e v_{i}=B_{0}+F E_{i}+B_{1}^{\top} Y_{i}+\varepsilon_{i}
$$

where again $Y_{i}$ represents a vector of firm characteristics (including bankruptcy costs, etc.) and the left hand side variable is one of the three leverage specifications ( $M L, Q M L$ and $B L)$. Leverage ratios were calculated with market and balance sheet data from the end of the third quarter 2008 and explanatory variables are based on data from the end of the second quarter 2008.

First, with respect to market leverage, we obtain the regression results of Table 5. We notice most importantly that bankruptcy costs enter with a significantly negative sign in the leverage ratio regression. This is the first direct evidence that the tradeoff theory of capital structure holds with respect to bankruptcy costs. We also find very significant negative effects from asset volatility. As before, section 5 shows that these results are not driven by spurious correlation induced by the estimation procedure. Most extant tests in the literature use accounting measures of asset volatility as derived for instance from earnings announcements or from the volatility of net-operating profits. There is weak and mixed evidence on the impact of volatility on leverage ratios. By contrast, we use a market-based measure of unlevered asset volatility. The strong negative effect from asset volatility also supports the tradeoff theory for capital structure since the higher the volatility the higher (for a given asset asset value) is the probability of default and therefore the higher are expected bankruptcy costs. Leverage is strongly positively related to tangibility, when assets are measured through our estimation procedure. We also find that leverage is negatively related to profitability, especially when profitability is measured with respect to estimated asset values. Our profitability results are consistent with findings in much of the existing empirical capital structure literature. Finally, we find strong evidence that market to book ratios are associated with lower debt ratios. This is especially true when we eliminate asset volatility and bankruptcy costs themselves from the set of regressors. We find that growth options can therefore have two effects on capital structure. One effect is the increase in bankruptcy costs already 
discussed; the second is an additional factor, such as underinvestment or other leverage related opportunity costs.

We repeat the regression analysis in Table 6 where leverage is measured by QML. Most of our previous results with market leverage are preserved in this specification. Although profitability becomes insignificant, it retains the same negative sign. We find the same results with respect to book leverage ratios in Table 7 , with the exception of the market to book ratio. While the market to book ratio, as a measure of investment opportunities, is negatively related to market based leverage definitions it is positively related to book leverage. This dichotomy of results regarding the leverage-profitability relation when leverage is measured by market values instead of book values has also been documented in the existing literature.12

In summary, we find that lower asset value risk implies a higher leverage ratio, a result that has not been documented in the existing literature. Tangibility of assets has a positive effect on leverage ratios. Firm size also enters in a positive way. Because both volatility and tangibility are separately controlled for, this represents a clean size effect that is not reflected otherwise. The market to book ratio has a negative effect on leverage as measured by market values but has a positive effect when using book leverage. Overall, the inclusion of the two new variables, firm-specific bankruptcy costs and firm-specific asset volatility explains the cross-section of leverage ratios much better than previous papers.

\subsection{Hidden Debt}

For our empirical analysis we took the debt level from the balance sheet of the firms and estimated, among other things, the default threshold implied by observed market prices. We did not require that the estimated default threshold be equal to the one that would be optimal for equityholders in the theoretical model, i.e. the one where the smooth-pasting condition is satisfied. In fact, we found considerable deviations from this "optimal" default threshold. As discussed above, covenants and agency considerations may play a role in this discrepancy. Another possibility, however, is, that the true set of liabilities faced by equityholders is not fully reflected in the accounting statements of the firm. For example, since our sample consists mostly of large US corporations, health care obligations can be an important liability omitted from the balance sheet. To investigate this, we explore the presence of such hidden debts. In order to implement this, we now assume that the actual default threshold equals the optimal threshold for equityholders inclusive of these hidden debts. Therefore we solve equation (5) for the $B$ which equates the theoretical with the estimated default barrier. We denote this implicit face value of total liabilities by $B^{H}$. Therefore $B^{H}$ satisfies

$$
B^{H}=\frac{1}{m}\left(\left[(1+(1-\alpha) \eta(z)+\alpha \eta(r)) A^{*}{ }_{B}+\frac{\tau C}{r} \eta(r)\right] \frac{r+m}{\eta(z)}-C\right) .
$$

For most of the firms in our sample, $B^{H}$ is greater than $B$, consistent with the existence of hidden debts. This

\footnotetext{
${ }^{12}$ See for instanceFrank \& Goyal (2009) and Fama \& French (2002).
} 
Table 5: This table contains the results for a regression of market leverage (ML) on various firm characteristic variables as indicated in the rows of the table. The variable definitions are in the text. The regression is performed for both firm characteristics using both balance sheet asset values and the asset values estimated from the model. The explanatory variables are from Q2 2008, the leverage ratios are calculated with Q3 2008 data. Significance levels are indicated by *** for $1 \%, * *$ for $5 \%$, and * for $10 \%$. Standard errors are given in parenthesis.

\begin{tabular}{|c|c|c|c|c|c|c|c|c|}
\hline & \multicolumn{4}{|c|}{ Balance Sheet Asset Value } & \multicolumn{4}{|c|}{ Estimated Asset Value } \\
\hline & $M L$ & $M L$ & ML & $M L$ & $M L$ & $M L$ & $M L$ & $M L$ \\
\hline \multirow[t]{2}{*}{ Constant } & $0.61 * * *$ & $0.67 * * *$ & $0.44 * * *$ & $0.40 * * *$ & $0.62 * * *$ & $0.70 * * *$ & $0.43^{* * *}$ & $0.36^{* * *}$ \\
\hline & $(0.09)$ & $(0.13)$ & (0.09) & $(0.12)$ & (0.09) & $(0.12)$ & $(0.09)$ & $(0.11)$ \\
\hline \multirow[t]{2}{*}{ Asset Volatility } & $-0.72 * * *$ & $-0.68 * * *$ & & & $-0.88 * * *$ & $-0.95 * * *$ & & \\
\hline & $(0.16)$ & $(0.19)$ & & & $(0.15)$ & $(0.18)$ & & \\
\hline \multirow[t]{2}{*}{$\alpha$} & $-0.16^{* * *}$ & $-0.14 * * *$ & & & $-0.12 * * *$ & $-0.09 * *$ & & \\
\hline & $(0.04)$ & $(0.04)$ & & & $(0.04)$ & $(0.04)$ & & \\
\hline \multirow[t]{2}{*}{ Log Assets } & $0.03 *$ & 0.02 & $0.06 * * *$ & $0.05^{* *}$ & 0.01 & 0.01 & $0.04 * *$ & $0.05^{* * *}$ \\
\hline & $(0.02)$ & $(0.02)$ & $(0.02)$ & $(0.02)$ & $(0.01)$ & $(0.02)$ & $(0.02)$ & $(0.02)$ \\
\hline \multirow[t]{2}{*}{ Tang w Cash } & $0.18^{* *}$ & $0.19 *$ & 0.06 & 0.13 & $0.53 * * *$ & $0.59 * * *$ & $0.49 * * *$ & $0.55^{* * *}$ \\
\hline & (0.09) & $(0.10)$ & $(0.09)$ & $(0.10)$ & $(0.08)$ & $(0.09)$ & $(0.09)$ & $(0.09)$ \\
\hline \multirow[t]{2}{*}{ Labor Intensity } & 3.95 & -5.64 & 3.70 & -4.91 & 4.50 & -5.14 & 4.35 & -3.73 \\
\hline & $(2.94)$ & $(6.63)$ & $(3.20)$ & (7.04) & $(2.74)$ & $(6.05)$ & (3.04) & $(6.57)$ \\
\hline \multirow[t]{2}{*}{ Pension Funding Gap } & 0.04 & -0.01 & 0.02 & -0.01 & -0.00 & -0.05 & -0.03 & -0.04 \\
\hline & $(0.06)$ & $(0.06)$ & $(0.06)$ & $(0.07)$ & $(0.06)$ & $(0.06)$ & $(0.06)$ & $(0.07)$ \\
\hline \multirow[t]{2}{*}{ Profitability } & $-1.03^{*}$ & $-1.56^{* *}$ & $-1.25^{* *}$ & $-1.80 * * *$ & $-2.19 * *$ & $-2.85 * * *$ & $-2.99 * * *$ & $-3.51 * * *$ \\
\hline & $(0.57)$ & $(0.64)$ & $(0.62)$ & $(0.68)$ & $(0.91)$ & (0.99) & $(1.00)$ & (1.07) \\
\hline \multirow[t]{2}{*}{ MTB } & $-0.04 * *$ & -0.03 & $-0.07 * * *$ & $-0.05^{* *}$ & -0.02 & -0.02 & $-0.08 * * *$ & $-0.06 * * *$ \\
\hline & $(0.02)$ & $(0.02)$ & $(0.02)$ & $(0.02)$ & $(0.01)$ & $(0.01)$ & $(0.01)$ & $(0.01)$ \\
\hline $\operatorname{adj} R^{2}$ & 0.43 & 0.48 & 0.32 & 0.41 & 0.50 & 0.56 & 0.39 & 0.48 \\
\hline Ind FE & $N$ & $Y$ & $N$ & $Y$ & $\mathrm{~N}$ & Y & $N$ & $Y$ \\
\hline $\mathrm{N}$ & 220 & 220 & 220 & 220 & 220 & 220 & 220 & 220 \\
\hline
\end{tabular}


Table 6: This table contains the results for a regression of quasi market leverage (QML) on various firm characteristic variables as indicated in the rows of the table. The variable definitions are in the text. The regression is performed for both firm characteristics using both balance sheet asset values and the asset values estimated from the model. The explanatory variables are from Q2 2008, the leverage ratios are calculated with Q3 2008 data. Significance levels are indicated by *** for 1\%,** for 5\% and * for $10 \%$. Standard errors are given in parenthesis.

\begin{tabular}{|c|c|c|c|c|c|c|c|c|}
\hline & \multicolumn{4}{|c|}{ Balance Sheet Asset Value } & \multicolumn{4}{|c|}{ Estimated Asset Value } \\
\hline & QML & QML & QML & QML & QML & QML & QML & QML \\
\hline Constant & $\begin{array}{c}0.41^{* * *} \\
(0.07)\end{array}$ & $\begin{array}{c}0.40 * * * \\
(0.10)\end{array}$ & $\begin{array}{c}0.27^{* * *} \\
(0.07)\end{array}$ & $\begin{array}{c}0.26 * * * \\
(0.09)\end{array}$ & $\begin{array}{c}0.48^{* * *} \\
(0.07)\end{array}$ & $\begin{array}{c}0.52 * * * \\
(0.09)\end{array}$ & $\begin{array}{c}0.32 * * * \\
(0.08)\end{array}$ & $\begin{array}{c}0.32 * * * \\
(0.09)\end{array}$ \\
\hline Asset Volatility & $\begin{array}{c}-0.65 * * * \\
(0.13)\end{array}$ & $\begin{array}{c}-0.39 * * * \\
(0.14)\end{array}$ & & & $\begin{array}{c}-0.83 * * * \\
(0.13)\end{array}$ & $\begin{array}{c}-0.64 * * * \\
(0.14)\end{array}$ & & \\
\hline$\alpha$ & $\begin{array}{c}-0.07 * * \\
(0.03)\end{array}$ & $\begin{array}{l}-0.06 * \\
(0.03)\end{array}$ & & & $\begin{array}{l}-0.04 \\
(0.03)\end{array}$ & $\begin{array}{l}-0.03 \\
(0.03)\end{array}$ & & \\
\hline Log Assets & $\begin{array}{c}0.06^{* * *} \\
(0.01)\end{array}$ & $\begin{array}{c}0.06 * * * \\
(0.01)\end{array}$ & $\begin{array}{c}0.08 * * * \\
(0.01)\end{array}$ & $\begin{array}{c}0.07^{* * *} \\
(0.01)\end{array}$ & $\begin{array}{c}0.03^{* *} \\
(0.01)\end{array}$ & $\begin{array}{c}0.03^{* *} \\
(0.01)\end{array}$ & $\begin{array}{c}0.05^{* * *} \\
(0.01)\end{array}$ & $\begin{array}{c}0.06 * * * \\
(0.01)\end{array}$ \\
\hline Tang w Cash & $\begin{array}{c}0.25^{* * *} \\
(0.07)\end{array}$ & $\begin{array}{c}0.27^{* * *} \\
(0.08)\end{array}$ & $\begin{array}{l}0.14^{*} \\
(0.07)\end{array}$ & $\begin{array}{c}0.24 * * * \\
(0.08)\end{array}$ & $\begin{array}{c}0.54 * * * \\
(0.07)\end{array}$ & $\begin{array}{c}0.55^{* * *} \\
(0.07)\end{array}$ & $\begin{array}{c}0.48^{* * *} \\
(0.07)\end{array}$ & $\begin{array}{c}0.51 * * * \\
(0.07)\end{array}$ \\
\hline Labor Intensity & $\begin{array}{c}0.67 \\
(2.42)\end{array}$ & $\begin{array}{l}-4.31 \\
(5.09)\end{array}$ & $\begin{array}{c}0.63 \\
(2.59)\end{array}$ & $\begin{array}{l}-3.94 \\
(5.22)\end{array}$ & $\begin{array}{c}0.90 \\
(2.27)\end{array}$ & $\begin{array}{l}-4.70 \\
(4.74)\end{array}$ & $\begin{array}{c}0.88 \\
(2.51)\end{array}$ & $\begin{array}{l}-3.85 \\
(4.98)\end{array}$ \\
\hline Pension Funding Gap & $\begin{array}{c}0.07 \\
(0.05)\end{array}$ & $\begin{array}{c}0.07 \\
(0.05)\end{array}$ & $\begin{array}{c}0.06 \\
(0.05)\end{array}$ & $\begin{array}{c}0.07 \\
(0.05)\end{array}$ & $\begin{array}{c}0.03 \\
(0.05)\end{array}$ & $\begin{array}{c}0.03 \\
(0.05)\end{array}$ & $\begin{array}{c}0.01 \\
(0.05)\end{array}$ & $\begin{array}{c}0.04 \\
(0.05)\end{array}$ \\
\hline Profitability & $\begin{array}{c}-1.19 * * \\
(0.47)\end{array}$ & $\begin{array}{c}-1.36 * * * \\
(0.49)\end{array}$ & $\begin{array}{c}-1.30 * * \\
(0.50)\end{array}$ & $\begin{array}{c}-1.45^{* * *} \\
(0.50)\end{array}$ & $\begin{array}{l}-1.40 * \\
(0.76)\end{array}$ & $\begin{array}{l}-1.52 * \\
(0.78)\end{array}$ & $\begin{array}{c}-2.08^{* *} \\
(0.83)\end{array}$ & $\begin{array}{c}-1.92 * * \\
(0.81)\end{array}$ \\
\hline MTB & $\begin{array}{c}-0.07 * * * \\
(0.01)\end{array}$ & $\begin{array}{c}-0.07 * * * \\
(0.01)\end{array}$ & $\begin{array}{c}-0.09 * * * \\
(0.02)\end{array}$ & $\begin{array}{c}-0.07 * * * \\
(0.01)\end{array}$ & $\begin{array}{c}-0.06 * * * \\
(0.01)\end{array}$ & $\begin{array}{c}-0.06 * * * \\
(0.01)\end{array}$ & $\begin{array}{c}-0.10 * * * \\
(0.01)\end{array}$ & $\begin{array}{c}-0.09 * * * \\
(0.01)\end{array}$ \\
\hline $\operatorname{adj} R^{2}$ & 0.60 & 0.68 & 0.55 & 0.67 & 0.65 & 0.73 & 0.57 & 0.70 \\
\hline Ind FE & N & Y & N & Y & N & Y & N & Y \\
\hline $\mathrm{N}$ & 220 & 220 & 220 & 220 & 220 & 220 & 220 & 220 \\
\hline
\end{tabular}


Table 7: This table contains the results for a regression of book leverage (BL) on various firm characteristic variables as indicated in the rows of the table. The variable definitions are in the text. The regression is performed for both firm characteristics using both balance sheet asset values and the asset values estimated from the model. The explanatory variables are from Q2 2008, the leverage ratios are calculated with Q3 2008 data. Significance levels are indicated by *** for 1\%, ** for 5\% and * for 10\%. Standard errors are given in parenthesis.

Balance Sheet Asset Value

Estimated Asset Value

\begin{tabular}{|c|c|c|c|c|c|c|c|c|}
\hline & $B L$ & $B L$ & $B L$ & $B L$ & $\mathrm{BL}$ & $B L$ & $\mathrm{BL}$ & $\mathrm{BL}$ \\
\hline \multirow[t]{2}{*}{ Constant } & $0.63 * * *$ & $0.68 * * *$ & $0.31^{* * *}$ & $0.27 * *$ & $0.71 * * *$ & $0.81^{* * *}$ & $0.39 * * *$ & $0.34 * *$ \\
\hline & (0.10) & $(0.13)$ & $(0.11)$ & $(0.14)$ & $(0.10)$ & $(0.13)$ & $(0.12)$ & $(0.13)$ \\
\hline \multirow[t]{2}{*}{ Asset Volatility } & $-1.46 * * *$ & $-1.29 * * *$ & & & $-1.59 * * *$ & $-1.43 * * *$ & & \\
\hline & $(0.18)$ & $(0.20)$ & & & $(0.18)$ & $(0.21)$ & & \\
\hline \multirow[t]{2}{*}{$\alpha$} & $-0.12 * * *$ & $-0.08 *$ & & & $-0.10 * *$ & -0.06 & & \\
\hline & $(0.05)$ & $(0.05)$ & & & $(0.05)$ & $(0.05)$ & & \\
\hline \multirow[t]{2}{*}{ Log Assets } & 0.03 & $0.03^{*}$ & $0.07 * * *$ & $0.08 * * *$ & 0.00 & 0.02 & $0.05^{* *}$ & $0.07 * * *$ \\
\hline & $(0.02)$ & $(0.02)$ & $(0.02)$ & $(0.02)$ & $(0.02)$ & $(0.02)$ & $(0.02)$ & $(0.02)$ \\
\hline \multirow[t]{2}{*}{ Tang w Cash } & $0.22 * *$ & $0.40 * * *$ & -0.01 & $0.26^{* *}$ & $0.40 * * *$ & $0.50 * * *$ & $0.30 * * *$ & $0.39 * * *$ \\
\hline & $(0.10)$ & $(0.11)$ & $(0.11)$ & $(0.12)$ & $(0.10)$ & $(0.10)$ & $(0.11)$ & $(0.11)$ \\
\hline \multirow[t]{2}{*}{ Labor Intensity } & 4.08 & -10.80 & 4.01 & -10.01 & 4.34 & $-11.60 *$ & 4.21 & -9.76 \\
\hline & (3.28) & $(6.97)$ & $(3.84)$ & $(7.80)$ & (3.23) & (6.89) & $(3.86)$ & $(7.77)$ \\
\hline \multirow[t]{2}{*}{ Pension Funding Gap } & -0.01 & -0.00 & -0.05 & 0.00 & -0.05 & -0.03 & -0.08 & -0.01 \\
\hline & $(0.07)$ & $(0.07)$ & $(0.08)$ & $(0.08)$ & $(0.07)$ & $(0.07)$ & $(0.08)$ & $(0.08)$ \\
\hline \multirow[t]{2}{*}{ Profitability } & $-1.66^{* *}$ & $-1.65^{* *}$ & $-1.84^{* *}$ & $-1.77^{* *}$ & -1.66 & -1.57 & $-2.93 * *$ & $-2.43 *$ \\
\hline & $(0.64)$ & $(0.68)$ & $(0.74)$ & $(0.75)$ & $(1.08)$ & (1.13) & $(1.28)$ & $(1.26)$ \\
\hline \multirow[t]{2}{*}{ MTB } & $0.10 * * *$ & $0.09 * * *$ & $0.06 * * *$ & $0.07 * * *$ & $0.10 * * *$ & $0.10 * * *$ & 0.01 & $0.04 * *$ \\
\hline & $(0.02)$ & $(0.02)$ & $(0.02)$ & $(0.02)$ & $(0.02)$ & $(0.02)$ & $(0.02)$ & $(0.02)$ \\
\hline $\operatorname{adj} R^{2}$ & 0.31 & 0.45 & 0.06 & 0.31 & 0.33 & 0.45 & 0.04 & 0.30 \\
\hline Ind FE & $N$ & Y & N & Y & N & Y & N & Y \\
\hline $\mathrm{N}$ & 220 & 220 & 220 & 220 & 220 & 220 & 220 & 220 \\
\hline
\end{tabular}


is true whenever the estimated default threshold is higher than the optimal default threshold, using balance sheet liabilities. However, sometimes $B^{H}$ is less than $B$, and in some cases $B^{H}$ is even negative (for 49 firms this is indeed the case).

One hypothesis for the existence of negative hidden debts is that firms in financial distress may be able to recontract with parties, such as their employees, under more favorable terms. Indeed this seems to have been the case for many of the airline bankruptcies that have occurred in recent years, e.g. American Airlines. For a theory on this subject, see Berk et al. (2010).

Figure 4 displays the distribution of the ratios of implied to balance sheet liabilities, $B^{H} / B$. We conjecture that in particular firms with large legacy costs due to retirees as well as other former employees would be candidates to have negative hidden debts. Also, firms with relatively high labor costs within an industry would be candidates to have negative hidden debts, since financial distress allows these firms to recontract.

Figure 4: Hidden Debt. This illustrates a histogram of the ratios of the total estimated debt levels (including hidden debt) divided by the balance sheet value of debt.

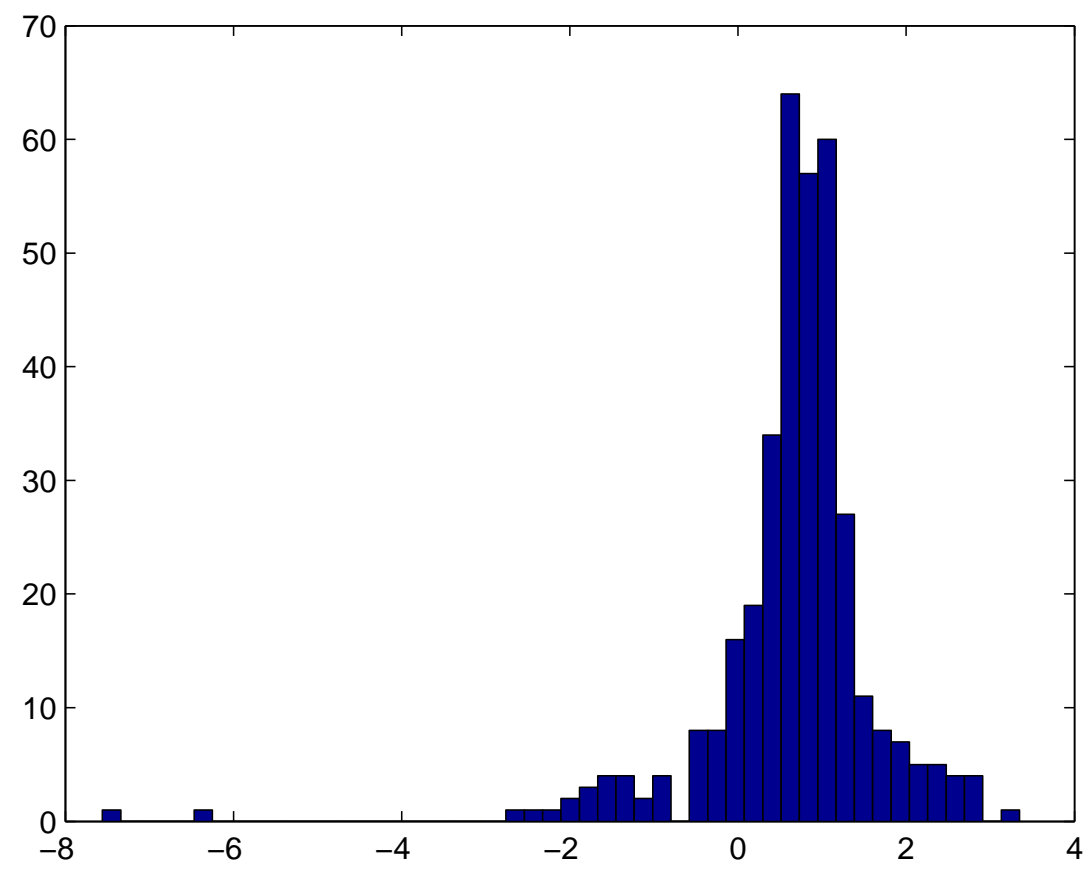

\section{Robustness}

We would like to use our structural model to understand how the empirical findings, in particular the negative relationship between leverage and asset volatility and between leverage and bankruptcy costs, are related to 
firms' capital structure decisions. We note that our estimation method does not impose on firms that they make either static or dynamically optimal capital structure decisions. All that is required by the framework of Leland that we employ is that the book value of debt stays constant over the estimation period. In order to interpret our results as evidence in favor of optimal capital structure decisions, it is therefore necessary to show that our relationships are not present in the absence of optimizing behavior.

First, we would like to explore to what extent the strong negative relation between asset volatility and leverage could be showing up even if firms are not optimally choosing their leverage ratios at the beginning of the sample period. To this end, we fix the book leverage and then derive market and quasi market leverage ratios from our theoretical pricing model for a representative firm with different unlevered asset volatilities. Figure 5 depicts the effect of asset volatility on market and quasi market-leverage, produced by the impact of asset volatility on theoretical equity and debt values via the default threshold and probability of default. Note that the slope is slightly negative, it is essentially zero for both market and quasi-market leverage ratios compared to the significantly negative empirical estimates.

Figure 5: Leverage vs. Asset Volalatility. This graph illustustrates the theoretical relationship between asset volatility on market leverage (blue, lower line) and on quasi market leverage (green upper line).

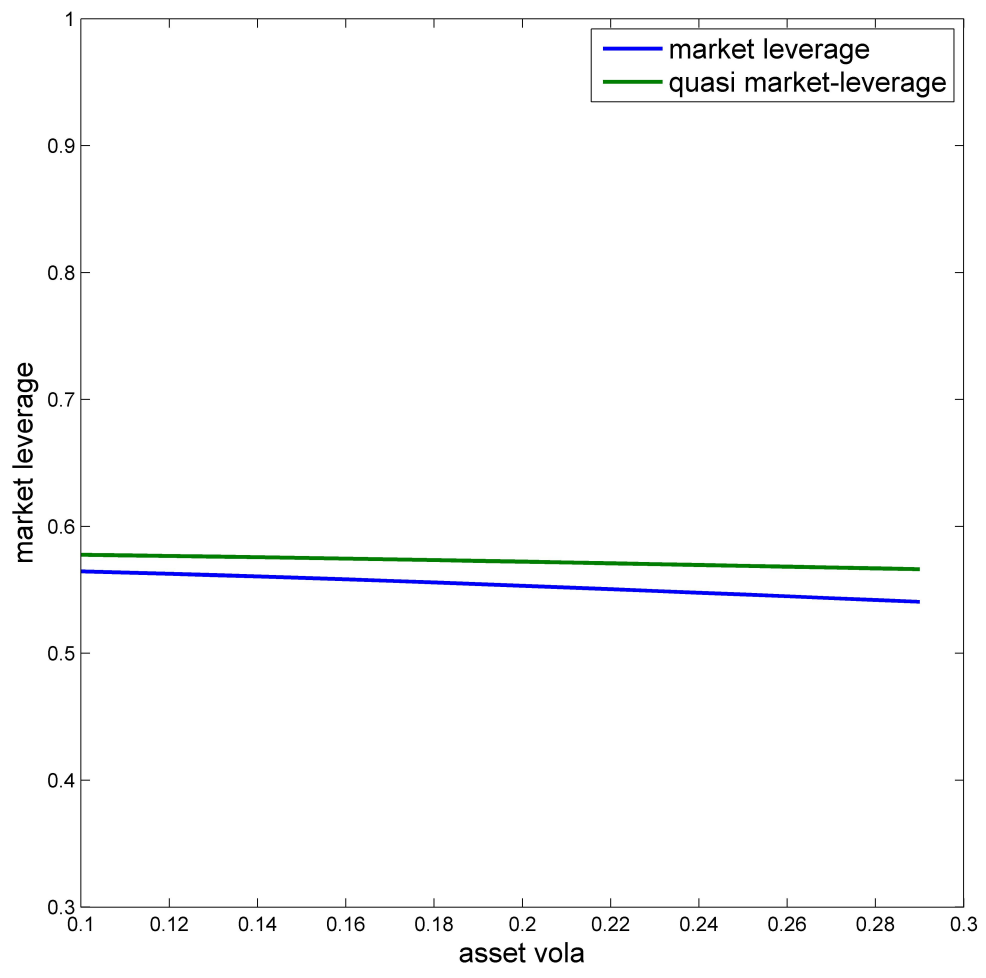

We have performed a similar exercise with respect to bankruptcy costs. Here, for fixed nominal debt levels, the theoretical relationship is actually positive, whereas the empirical evidence is strongly negative. 
Second, we want to ensure that the observed negative relation between leverage and asset volatility and leverage and bankruptcy costs is not purely an artifact of our estimation procedure. To check whether the pronounced negative relation between leverage and asset volatility or bankruptcy costs is generated artificially we test our estimation method on simulated data. We construct a sample of firms which, by assumption, does not exhibit a negative correlation between leverage and asset volatility or bankruptcy costs. For all firms, the asset volatility and the bankruptcy costs are the same but the book value of debt varies. Given these parameters we simulate sample paths of equity and option prices for 60 firms. Then we estimate the structural parameters of the firms in the same fashion as we did for the actual data.

Figure 6 depicts the outcome of the simulation with respect to estimated volatilities. The blue points represent the true quasi market leverage ratios of the firms in the simulation. The volatility was fixed at $\sigma=0.2$ while the market leverage ratio varied between lev $=0.58$ and lev $=0.72$ for the simulated firms. The red points depict the corresponding estimated values of asset volatility. The correlation between estimated asset volatilities and estimated market leverage is close to zero (0.03), indicating that the estimation procedure does not impose the documented negative correlation between these two variables. Similarly 7 illustrates

Figure 6: Leverage vs. Asset Volatility. This illustrates the results of a simulation study in which sixty artificial firms were simulated with different leverage ratios but the same asset volatility. The linear blue dots indicate the true values and the red random dots indicate the results from the simulation.

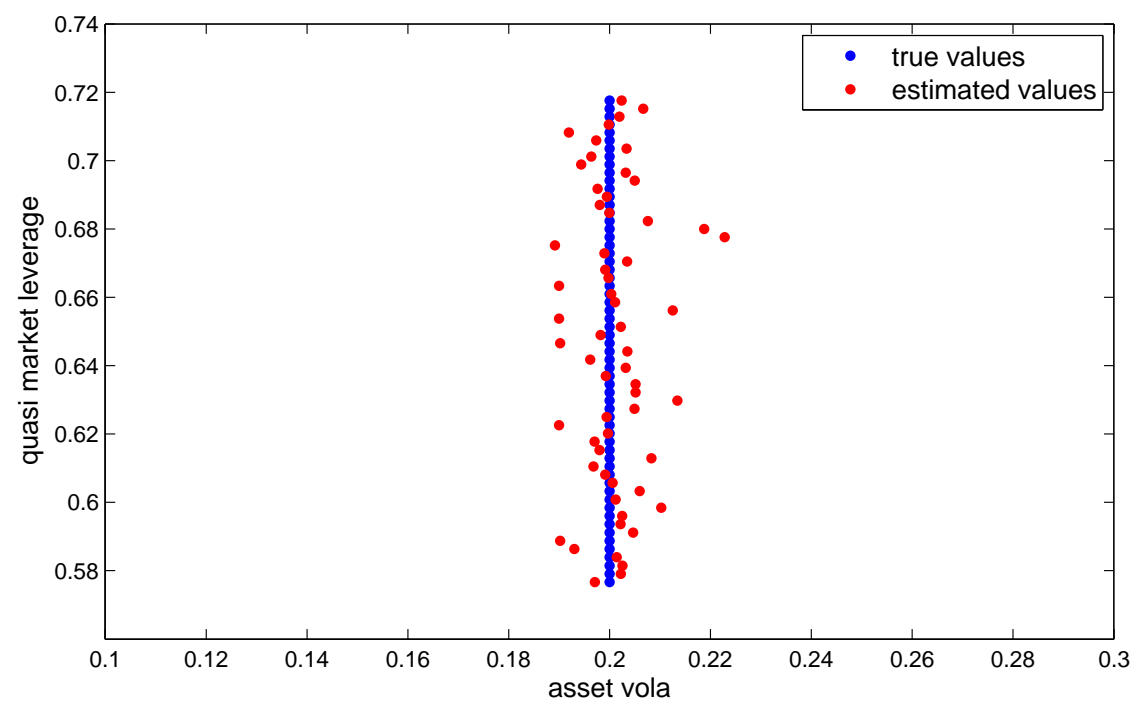

the estimates of bankruptcy cost obtained by simulating all 60 firms in the study. The true bankruptcy cost value is fixed at $\alpha=0.25$. The blue points represent the true values, while the red points indicate the estimated bankruptcy cost values. While there is more estimation error in determining the bankruptcy cost than with respect to unlevered asset volatilities, there is no noticeable bias in the estimates. The correlation between bankruptcy costs and leverage is somewhat higher than that for volatilities $(-0.07)$ but also 
insignificant. Table 8 summarizes the results of our simulation study. Since the mean of the estimates equals

Figure 7: Leverage vs. Bankruptcy Costs. This illustrates the results of a simulation study in which sixty artificial firms were simulated with different leverage ratios but the same bankruptcy cost. The linear blue dots indicate the true values and the red random dots indicate the results from the simulation.

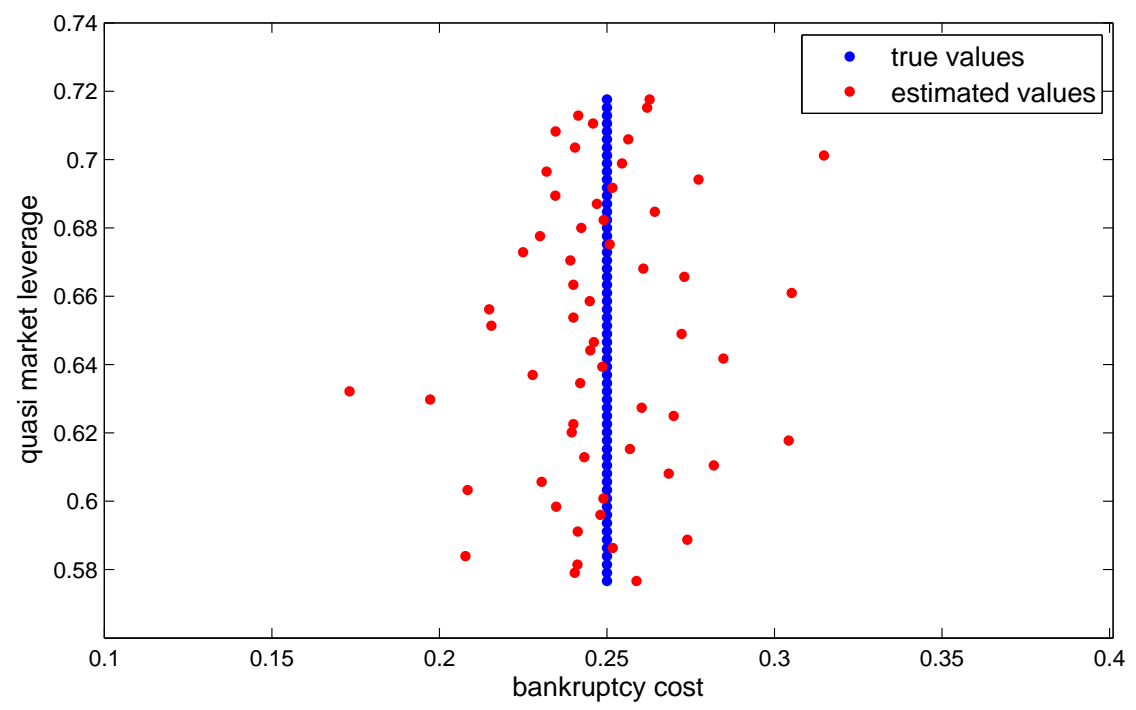

exactly the true values for volatility and bankruptcy cost, there is no bias in either. The mean squared errors for volatility are lower than for the bankruptcy costs. Nevertheless, the square root of the MSE for bankruptcy cost is a small fraction of the average estimate. This table also reports the correlations with leverage and the cross-correlation and shows that they are all insignificantly different from zero using a $t$-test.

Table 8: Simulation Results: This table reports the results of a simulation study in which sixty artificial firms were simulated with different leverage ratios but the same asset volatility and bankruptcy cost.

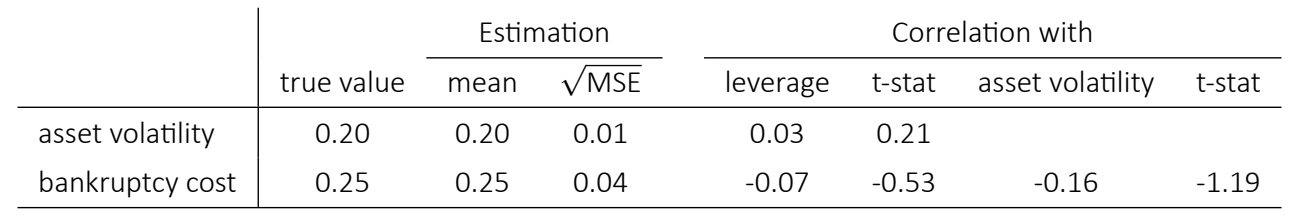

We have also computed the confidence bounds for both bankruptcy cost and volatility in the simulation. We find that $95 \%$ of the time, the bankruptcy cost is between 0.20 and 0.31 while the true value is 0.25 . For asset volatilities, the $95 \%$ confidence band is between 0.19 and 0.22 for a true value of 0.20 .

Third, we want to test whether the positive relationship between a firm's bankruptcy costs and its asset volatility documented in table 3 is a spurious result of the estimation procedure. The correlation between the true bankruptcy costs and asset volatilities is zero in our simulated sample of 60 firms, because both values are fixed as constants. As table 8 reports, the slightly negative correlation of the estimated parameters is not 
significantly different from zero. This is also illustrated in figure 8 .

Figure 8: Bankruptcy Costs vs Asset Volatility: This illustrates the results of a simulation study in which sixty artificial firms were simulated with different leverage ratios but the same bankruptcy cost and asset volatility. The true values for asset volatility and bankruptcy cost are 0.2 and 0.25 and are represented by the crossing point of the blue lines. The red random dots indicate the results from the estimation.

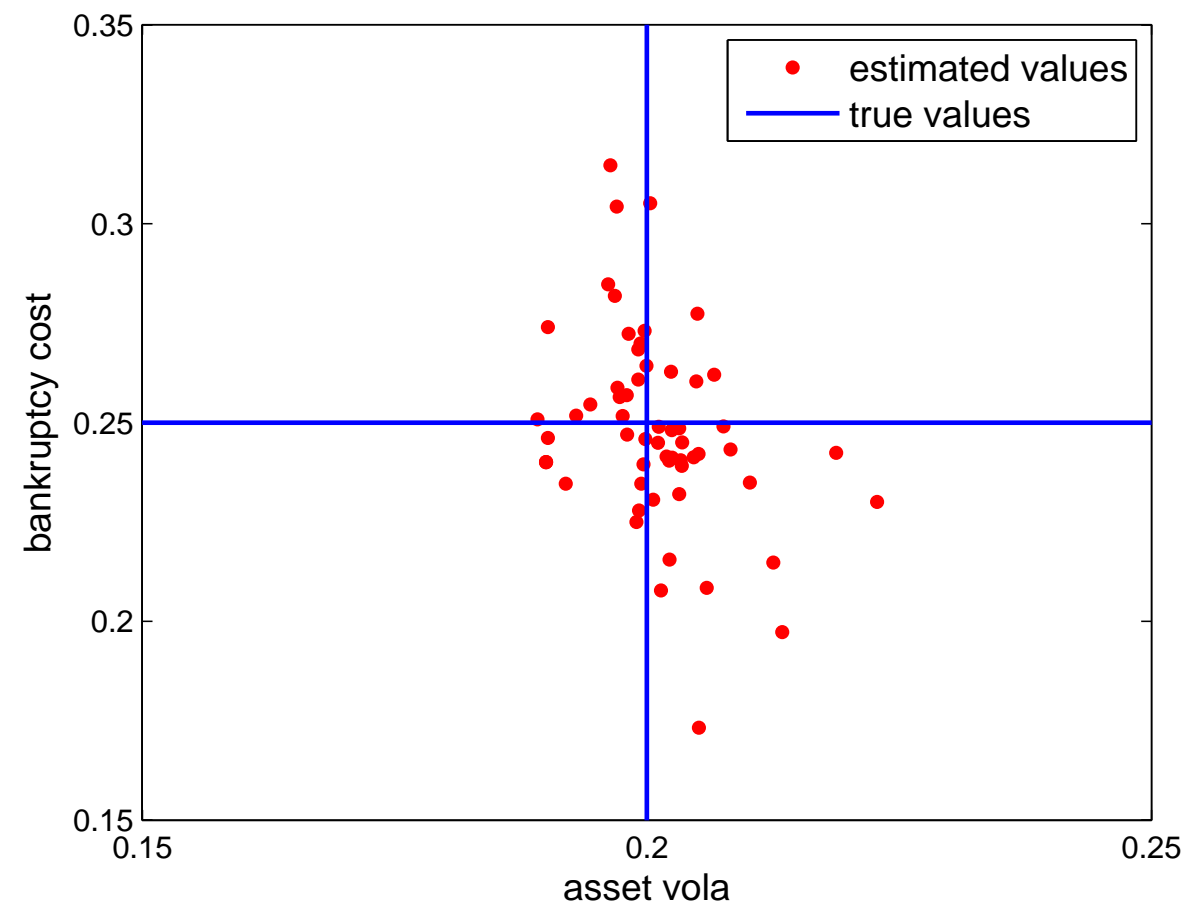

\section{Conclusions}

As part of the literature on capital structure, the issue of the magnitude of bankruptcy costs has been recognized as having fundamental importance. In order to reconcile observed debt levels, if there is any relevance to the tradeoff theory of capital structure, bankruptcy costs should be economically significant. However measuring these costs has been fraught with considerable difficulty. For one thing, there are small samples of firms that have actually gone bankrupt. For another, observing total bankruptcy costs is not easy and often omits indirect and opportunity costs. Finally, there is a well-known selection bias in extending ex post observations to ex ante expectations.

This paper has taken a novel approach to this critical subject. We have utilized a broad based sample of S\&P 500 firms in 2007, and applied a new method for inferring bankruptcy costs from equity and equitylinked put option prices during 2008 to 2010. Unlike previous approaches, our sample does not suffer by 
only considering highly levered firms or ones that have gone bankrupt. While it may appear unusual to base bankruptcy cost estimates on prices of residual claimants whose claims are worthless no matter what happens in bankruptcy, we are able to do so by using a structural model of capital structure dynamics. In this model, old debt is continually refinanced and the surplus or deficit accrues to equityholders. As a result equity valuations are a function of ex post bankruptcy costs as measured by a percentage of asset values at the onset of the bankruptcy process. The use of put options is shown to be integral to the implementation of the method as these are even more sensitive to bankruptcy probabilities, traded on organized exchanges as standardized contracts and are liquid. This avoids the need to rely on debt prices such as CDS which unfortunately do not fully reflect the heterogeneity of debt structures, and are subject to counterparty risk. We illustrate the efficacy of our method by utilizing data from the financial crisis period, which was characterized by wild swings in stock markets. Applying this estimation procedure using Kalman filtering techniques gives specific estimates that are reasonable and significant in magnitude -- averaging $20 \%$ of unlevered asset values. Our paper thus provides the first broad based study of ex ante bankruptcy cost estimates by industry and illustrates considerable variation. We perform a cross-sectional analysis to uncover the determinants of bankruptcy costs. We found that asset volatility and growth options as measured by market to book ratios have significant positive impacts, while tangibility and size have negative impacts. Less significant are pension deficits and labor intensity. It is important to our conclusions that standard firm characteristic variables do not fully explain our bankruptcy cost estimates. This implies that our new method has potential in augmenting tests for capital structure theories.

In order to operationalize this idea, we perform a true direct cross-sectional test of the determinants of leverage ratios during 2008. We augment our regressors consisting of firm characteristic variables by including the firm-specific bankruptcy cost estimates and show that explanatory power is significantly larger. As another byproduct from our approach, we are able to estimate market values for debt securities, thus enabling us to analyze market leverage ratios in addition to book leverage ratios. Our bankruptcy cost variable estimate significantly negatively impacts leverage ratios. This negative impact is over and above that of other firm characteristics such as asset intangibility and asset volatility. We also find a negative leverage profitability relationship using market leverage values, consistent with earlier literature. In sum, we find strong support for the tradeoff theory of capital structure.

In a final application of our method, we infer hidden debts that are not present on balance sheets in any way. These are debts which could conceivably be expunged in bankruptcy that may reduce net bankruptcy costs. The best examples are long term legacy contracts that may not reflect current labor market conditions. While there is more room for work in this area, we believe that our study supports the view that hidden debts can be another significant factor in explaining likelihoods and consequences of bankruptcy. 


\section{A Derivation of the Put Pricing Formula}

Let $(\Omega, F, \mathcal{F}, P)$ be a filtered probability space with the filtration $\mathcal{F}=\left\{F_{t}: t \geq 0\right\}$ generated by the Brownian motion $W_{t}^{P}$, and let $Q \sim P$ be the martingale measure with the risk-free bank account as the numeraire. The $Q$-dynamics of the unlevered asset value process $A_{t}$ are given by

$$
d A_{t}=\left(\mu_{B}+\frac{\sigma^{2}}{2}\right) A_{t} d t+\sigma A_{t} d W_{t}
$$

where $W_{t}$ is a $Q$-Wiener process and $\mu_{B}=r-\delta-\frac{\sigma^{2}}{2}$ is the drift of $\ln A_{t}$.

The payoff of a put option, (17), depends on whether the underlying firm has defaulted or not:

$$
P_{T}=\left(K-S\left(A_{T}\right)\right)^{+} 1_{T_{B}>T}+K 1_{T_{B} \leq T}
$$

In order to derive the price of the option at time 0 , we first define $A^{*}$ as the time- $T$ unlevered asset value such that the option is at the money $\left(S\left(T, A^{*}\right)=K\right)$. If markets are arbitrage free, the put price can be written as the discounted expected value of the payoff, with the risk-free rate serving as the discount rate under the risk-neutral measure $Q$ :

$$
P_{0}=e^{-r T} E_{0}^{Q}\left[\left(K-S\left(A_{T}\right)\right) 1_{A_{T} \leq A^{*} \wedge T_{B}>T}\right]+K e^{-r T} E^{Q}\left[1_{T_{B} \leq T}\right]
$$

with the stock price given by

$$
\begin{aligned}
S\left(A_{T}\right)= & A_{T}+\frac{\tau C}{r}\left[1-G\left(T, A_{T}\right)\right]-\alpha A_{B} G\left(T, A_{T}\right) \\
& -\frac{C+m B}{z}\left[1-G^{z}\left(T, A_{T}\right)\right]-(1-\alpha) A_{B} G^{z}\left(T, A_{T}\right)
\end{aligned}
$$

The pricing formula (18) includes the stochastic variable $A_{T}$, as well as $G\left(T, A_{T}\right)$ and $G^{z}\left(T, A_{T}\right)$ which are nonlinear functions of $A_{T}$ together with the indicator function $1_{Y_{T}}$ where $Y_{T}=\left\{A_{T} \leq A^{*} \wedge T_{B}>T\right\}$ is the event that the option is in the money and the firm has not defaulted prior to maturity of the option. As the put formula can be expressed as terms involving the payoffs $A_{T} 1_{Y_{T}}, G\left(T, A_{T}\right) 1_{Y_{T}}$, and $G^{z}\left(T, A_{T}\right) 1_{Y_{T}}$ we will derive their time- 0 values explicitly in the next three lemmas. To facilitate calculations we will change the probability measure by choosing convenient likelihood processes (see Ericsson \& Reneby, 1998, 2003, for a discussion of this approach). We make sure that the likelihood processes are chosen in such a way as to guarantee that the new measures are also probability measures. In addition, the new measures will be martingale measures with $A_{T}, G\left(T, A_{T}\right)$, and $G^{z}\left(T, A_{T}\right)$ as the respective numeraires. Finally, Girsanov's theorem (see Duffie, 2001, app D) will tell us the drift rate of $A_{t}$ under the new measures.

The first term involves the time- $T$ value of the unlevered asset price. For this transformation we use the unlevered asset value as 'numeraire'. 
Lemma A.1 The price of the time-T payoff $A_{T} 1_{Y_{T}}$ at time 0 is given by

$$
E_{0}^{Q}\left[e^{-r T} A_{T} 1_{Y_{T}}\right]=A_{0} e^{-\delta T} Q^{A}\left(Y_{T}\right)
$$

with the likelihood process

$$
L_{Q}^{A}(t)=\frac{d Q^{A}}{d Q}, \quad \text { on } F_{t}, \quad 0 \leq t \leq T
$$

given by

$$
L_{Q}^{A}(t)=\frac{A_{t} e^{\delta t}}{B_{t} A(0)}
$$

The Girsanov kernel for the transition from $Q$ to $Q^{A}$ is equal to $\sigma$ which changes the drift of $A$ under $Q^{A}$ to

$$
\mu_{A}=\mu_{B}+\sigma^{2}
$$

Proof The Likelihood process $L_{Q}^{A}(t)=\frac{A_{t} e^{\delta t}}{B_{t} A(0)}$ is a $Q$-martingale and $E_{0}^{Q}\left[L_{Q}^{A}(T)\right]=1$. The pricing formula (19) follows from $E_{0}^{Q}\left[e^{-r T} A_{T} 1_{Y_{T}}\right]=E_{0}^{A}\left[L_{A}^{Q}(T) e^{-r T} A_{T} 1_{Y_{T}}\right]$ where $L_{A}^{Q}(t)=\frac{1}{L_{Q}^{A}(t)}$.

$$
\begin{aligned}
E_{0}^{Q}\left[e^{-r T} A_{T} 1_{Y_{T}}\right] & =E_{0}^{A}\left[\frac{B_{T} A_{0} e^{-\delta T}}{B_{0} A_{T}} e^{-r T} A_{T} 1_{Y_{T}}\right] \\
& =A_{0} e^{-\delta T} E_{0}^{A}\left[1_{Y_{T}}\right] \\
& =A_{0} e^{-\delta T} Q^{A}\left(Y_{T}\right)
\end{aligned}
$$

To derive the price of the future $\$ 1$ in-default claim, we use this claim itself to factor it out of the expectation.

Lemma A.2 The price of the time-T payoff $G\left(T, A_{T}\right) 1_{Y_{T}}$ at time 0 is given by

$$
E_{0}^{Q}\left[e^{-r T} G\left(T, A_{T}\right) 1_{Y_{T}}\right]=G\left(0, A_{0}\right) Q^{G}\left(Y_{T}\right)
$$

In this case, the likelihood process is given by

$$
L_{Q}^{G}(t)=\frac{G\left(t, A_{t}\right)}{B_{t} G\left(0, A_{0}\right)}
$$

The Girsanov kernel for the transition from $Q$ to $Q^{G}$ is equal to $-\eta(r) \sigma$ which changes the drift of $A$ under $Q^{G}$ to

$$
\mu_{G}=\mu_{B}-\eta(r) \sigma^{2}
$$


Proof The steps of the proof are the same as for lemma A.1.

The final term involves $G^{Z}\left(T, V_{T}\right)$ which is a claim to $e^{-m\left(T_{B}-T\right)}$ dollars if the firm defaults at $T_{B}$.

Lemma A.3 The price of the time-T payoff $G^{2}\left(T, A_{T}\right) 1_{Y_{T}}$ at time 0 is given by

$$
E_{0}^{Q}\left[e^{-r T} G^{Z}\left(T, A_{T}\right) 1_{Y_{T}}\right]=e^{m T} G^{z}\left(0, A_{0}\right) Q^{z}\left(Y_{T}\right)
$$

with the likelihood process given by

$$
L_{Q}^{z}(t)=\frac{G^{z}\left(t, A_{t}\right) e^{-m t}}{B_{t} G^{z}\left(0, A_{0}\right)}
$$

The Girsanov kernel for the transition from $Q$ to $Q^{z}$ is equal to $-\eta(z) \sigma$ which changes the drift of $A$ under $Q^{z}$ to

$$
\mu_{z}=\mu_{B}-\eta(z) \sigma^{2}
$$

Proof The steps of the proof are the same as for lemma A.1.

The put pricing formula contains the probability of the event $Y_{t}$ evaluated under different martingale measures with respect to different numeraires, namely, $A_{t}, G\left(t, A_{t}\right)$, and $G^{z}\left(t, A_{t}\right)$. The probabilities $Q\left(A_{T}\right)$, $Q^{A}\left(A_{T}\right), Q^{G}\left(A_{T}\right)$, and $Q^{z}\left(A_{T}\right)$ can be easily derived from the density of an absorbed Brownian motion with the respective drift rates $\hat{\mu}, \mu_{A}, \mu_{G}$, and $\mu_{z}$ (e.g. Bjoerk, 2004, ch 18).

Using the previous results, the price of the put option is stated in the following proposition:

Proposition A.4 Given the Q-dynamics of $A_{t}$ in (16), the price of the put option with time-T payoff defined in (17) is

$$
\begin{aligned}
P_{t}= & e^{-r(T-t)} K\left(Q\left(Y_{T}\right)+Q\left(T_{B}<T\right)\right)-A_{t} e^{-\delta(T-t)} Q^{A}\left(Y_{T}\right) \\
& -\frac{\tau C}{r}\left(e^{-r(T-t)} Q\left(Y_{T}\right)-G\left(t, A_{t}\right) Q^{G}\left(Y_{T}\right)\right)+\alpha A_{B} G\left(t, A_{t}\right) Q^{G}\left(Y_{T}\right) \\
& +\frac{C+m B}{z}\left(e^{-r(T-t)} Q\left(Y_{T}\right)-e^{m(T-t)} G^{z}\left(t, A_{t}\right) Q^{z}\left(Y_{T}\right)\right) \\
& +(1-\alpha) A_{B} e^{m(T-t)} G^{z}\left(t, A_{t}\right) Q^{z}\left(Y_{T}\right)
\end{aligned}
$$

\section{B The Unscented Kalman Filter}

Our model has the following state space representation:

$$
\begin{aligned}
& x_{t}=A+F x_{t-1}+\varepsilon_{t} \\
& y_{t}=g\left(x_{t}\right)
\end{aligned}
$$


As explained in section 3.1, the state equation comprises the process for the unlevered asset value and the $\operatorname{AR}(1)$ specification for the pricing errors, i.e. $x_{t}=\left(v_{t}, e_{t}^{S}, e_{t}^{p}\right)^{\prime}$, where $v_{t}$ is the log asset-value and $e_{t}^{S}, e_{t}^{p}$ are the pricing errors for the stock and the put price. Therefore, the covariance matrix of the state equation errors $(Q)$ contains the asset volatility and the variance of the noise terms in the pricing error processes.

$$
\begin{aligned}
Q & =E\left[\varepsilon \varepsilon^{\prime}\right] \\
& =\left(\begin{array}{ccc}
\sigma_{V}^{2} & 0 & 0 \\
0 & \sigma_{S}^{2} & 0 \\
0 & 0 & \sigma_{P}^{2}
\end{array}\right)
\end{aligned}
$$

The measurement equation (25), which summarizes equation (10) in vector form, contains the two observable security prices, the stock price and the put option price $\left(y_{t}=\left(s_{i, t}, p_{i, t}\right)^{\prime}\right)$. The non linear pricing functions $g$ can be further simplified to $g_{i}\left(x_{t}, \vartheta\right)=\bar{g}_{i}\left(v_{t}, \vartheta\right)+e_{t}^{i}, i \in\{S, P\}$ with only $v_{t}$ entering the non linear part.

As the state equation (24) is linear, the state propagation is the same as in the linear Kalman filter. Therefore, the update of the state variable and its mean squared error matrix (MSE), $P_{t \mid t-1}$, is given by:

$$
\begin{aligned}
& \hat{x}_{t \mid t-1}=A+B \hat{x}_{t \mid t} \\
& P_{t \mid t-1}=F P_{t \mid t} F^{\prime}+Q
\end{aligned}
$$

The measurement update, however, differs, since the state variables enter in a non linear way in the measurement equation (25). To approximate the distribution of $y_{t}$, which is a non linear transformation of the distribution of $x_{t}$, we rely on the unscented Kalman filter (see Wan \& Van Der Merwe, 2001, for a detailed description) to give us an approximation for the mean and the covariance matrix. The unscented transformation captures the true mean and covariance matrix of the prices accurately to the third order (if $V_{t}$ where not Gaussian, then to the second order). Figure 9 depicts the gain in accuracy obtained by the use of the unscented transformation.

We construct $2 L+1$ sigma vectors, $\chi_{i}$, where $L=2$ is the number of state variables. The sigma vectors are chosen in such a way that the mean and the covariance matrix of $y_{t}$ is approximated accurately up to the third order. Each sigma vector comes with corresponding weights, $W_{i}^{m}$ and $W_{i}^{c}$, to calculate the mean and the covariance matrix is the weighted average of the sigma points. The sigma vectors and weights are given by

$$
\begin{array}{lll}
\chi_{0}=\hat{x}_{t \mid t-1} & W_{0}^{m}=\frac{\lambda}{\lambda+L} & W_{0}^{c}=\frac{\lambda}{\lambda+L}+1-\alpha^{2}+b \\
\chi_{i}=\hat{x}_{t \mid t-1}+\sqrt{(L+\lambda)\left(P_{t \mid t-1}\right)_{i}} & W_{i}^{m}=W_{i}^{c}=\frac{1}{2(\lambda+L)} & i=1, \ldots, L \\
\chi_{i}=\hat{x}_{t \mid t-1}-\sqrt{(L+\lambda)\left(P_{t \mid t-1}\right)_{i-L}} & W_{i}^{m}=W_{i}^{c}=\frac{1}{2(\lambda+L)} & i=L+1, \ldots, 2 L
\end{array}
$$



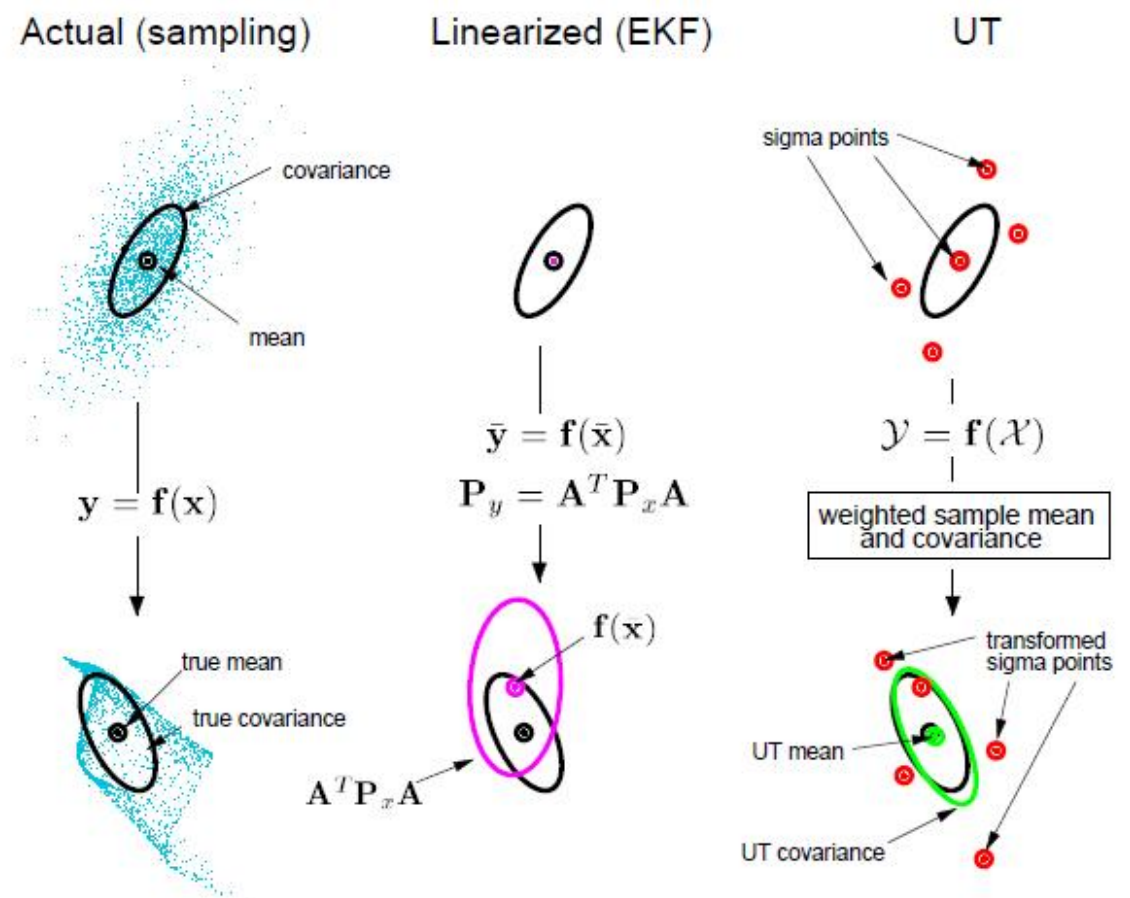

Figure 9: Example for the unscented transformation for mean and covariance propagation comparing actual moments to moments derived under first-order linearization (extended Kalman filter), and unscented Kalman filter. Source: Wan \& Van Der Merwe (2001). 
where $\lambda=\alpha^{2}(L+\kappa)-L, B=2$, and $\alpha \ldots$ The non-linear function $g$ is than applied to the sigma vectors $y_{i}=g\left(\chi_{i}\right), i=0, \ldots, 2 L$. The measurement update is then given by

$$
\begin{aligned}
\hat{y}_{t \mid t-1} & =\sum_{i=0}^{2 L} W_{i}^{m} y_{i} \\
\Psi_{t} & =\sum_{i=0}^{2 L} W_{i}^{c}\left(y_{i}-\hat{y}_{t \mid t-1}\right)\left(y_{i}-\hat{y}_{t \mid t-1}\right)^{\prime} \\
P_{t \mid t-1}^{x y} & =\sum_{i=0}^{2 L} W_{i}^{c}\left(\chi_{i}-\hat{x}_{t \mid t-1}\right)\left(y_{i}-\hat{y}_{t \mid t-1}\right)^{\prime} \\
K_{t} & =P_{t \mid t-1}^{x y} \Psi^{-1} \\
\hat{x}_{t \mid t} & =\hat{x}_{t \mid t-1}+K_{t}\left(y_{t}-\hat{y}_{t \mid t-1}\right) \\
P_{t \mid t} & =P_{t \mid t-1}+K_{t} \Psi_{t} K_{t}^{\prime}
\end{aligned}
$$

Finally, the log-likelihood function is given by

$$
I_{t}(\hat{\vartheta})=-\frac{1}{2} \log \left|\Psi_{t}\right|-\frac{1}{2}\left(y_{t}-\hat{y}_{t \mid t-1}\right) \Psi_{t}^{-1}\left(y_{t}-\hat{y}_{t \mid t-1}\right)^{\prime}
$$




\section{Description of Regressors}

Table 9: This table contains the description of all variables used in the regressions of bankruptcy costs and leverage ratios.

\begin{tabular}{|c|c|}
\hline Variable & Description \\
\hline Firm size & $\begin{array}{l}\text { Logarithm of total assets; we either use the balance sheet value } \\
\text { of total assets or our estimate of the unlevered asset value. }\end{array}$ \\
\hline Tangibility/Assets & $\begin{array}{l}\text { Tangibility is quantified by the measure from Berger et al. (1996) } \\
\text { which was also used in Almeida \& Campello (2007). The mea- } \\
\text { sure is defined as Tangibility }=0.715 \times \text { Receivables }+0.547 \times \\
\text { Inventory }+0.535 \times \text { Capital, where Capital equals property, plant } \\
\text { and equipment. Cash holdings are added to this value and the } \\
\text { sum is scaled by total assets }\end{array}$ \\
\hline Labor intensity & Number of employees over sales. \\
\hline R\&D/Assets & $\begin{array}{l}\text { R\&D expenses over total assets where assets either correspond to } \\
\text { the balance sheet value or to the estimated unlevered asset value. }\end{array}$ \\
\hline Pension funding gap & $\begin{array}{l}\text { Following Rauh (2009) we construct a measure of the pension gap } \\
\text { as the ratio of pension assets minus pension liabilities to pension } \\
\text { liabilities. Pension assets correspond to the fair value of plan as- } \\
\text { sets and pension liabilities to the projected benefit obligation. }\end{array}$ \\
\hline Profitability & $\begin{array}{l}\text { Profitability equals after-tax operating income before depreciation } \\
\text { divided by total assets taken either from the balance sheet or from } \\
\text { the estimation results. }\end{array}$ \\
\hline MTB & $\begin{array}{l}\text { Market-to-book ratio is defined in the numerator by the market } \\
\text { value of equity + short-term debt + long term debt + preferred } \\
\text { liquidation value - deferred taxes and investment tax credits. In } \\
\text { the denominator the book value of total assets is used. }\end{array}$ \\
\hline
\end{tabular}




\section{References}

Almeida, H. \& Campello, M. (2007). Financial constraints, asset tangibility, and corporate investment. Review of Financial Studies, 20(5), pp. 1429--1460.

Almeida, H. \& Philippon, T. (2007). The risk-adjusted cost of financial distress. Journal of Finance, 62(6), 2557--2586.

Altman, E. I. (1984). A further empirical investigation of the bankruptcy cost question. Journal of Finance, 39(4), pp. 1067--1089.

Andrade, G. \& Kaplan, S. N. (1998). How costly is financial (not economic) distress? evidence from highly leveraged transactions that became distressed. Journal of Finance, 53(5), 1443--1493.

Ang, J. S., Chua, J. H., \& McConnell, J. J. (1982). The administrative costs of corporate bankruptcy: A note. Journal of Finance, 37(1), pp. 219--226.

Bakshi, G., Kapadia, N., \& Madan, D. (2003). Stock return characteristics, skew laws, and the differential pricing of individual equity options. Review of Financial Studies, 16(1), 101--143.

Bates, D. S. (2000). Post-' 87 crash fears in the s\&p 500 futures option market. Journal of Econometrics, 94(1-2), 181--238.

Berger, P. G., Ofek, E., \& Swary, I. (1996). Investor valuation of the abandonment option. Journal of Financial Economics, 42(2), 257 -- 287.

Berk, J. B., Stanton, R., \& Zechner, J. (2010). Human capital, bankruptcy, and capital structure. Journal of Finance, 65(3), 891--926.

Bjoerk, T. (2004). Arbitrage Theory in Continuous Time. Oxford: Oxford University Press.

Bris, A., Welch, I., \& Zhu, N. (2006). The costs of bankruptcy: Chapter 7 liquidation versus chapter 11 reorganization. Journal of Finance, 61(3), 1253--1303.

Carr, P. \& Wu, L. (2010). Stock options and credit default swaps: A joint framework for valuation and estimation. Journal of Financial Econometrics, 8(4), 409--449.

Dangl, T. \& Zechner, J. (2007). Debt Maturity and the Dynamics of Leverage. SSRN Working Paper Series 89022.

Davydenko, S. A., Strebulaev, I. A., \& Zhao, X. (2012). A market-based study of the cost of default. Review of Financial Studies, 25(10), 2959--2999.

Duan, J.-C. (1994). Maximum likelihood estimation using price data of the derivative contract. Mathematical Finance, 4(2), 155--167. 
Duffie, D. (2001). Dynamic Asset Pricing Theory. 3rd edition.

Elkamhi, R., Ericsson, J., \& Parsons, C. (2012). The cost and timing of financial distress. Journal of Financial Economics, forthcoming.

Ericsson, J. \& Reneby, J. (1998). A framework for valuing corporate securities. Applied Mathematical Finance, 5(3-4), 143--163.

Ericsson, J. \& Reneby, J. (2003). Stock options as barrier contingent claims. Applied Mathematical Finance, 10(2), 121--147.

Ericsson, J. \& Reneby, J. (2005). Estimating structural bond pricing models. Journal of Business, 78(2), 707-706.

Ericsson, J., Reneby, J., \& Wang, H. (2007). Can structural models price default risk? new evidence from bond and credit derivative markets. working paper.

Fama, E. F. \& French, K. R. (2002). Testing trade?off and pecking order predictions about dividends and debt. Review of Financial Studies, 15(1), 1--33.

Frank, M. Z. \& Goyal, V. K. (2009). Capital structure decisions: Which factors are reliably important? Financial Management, 38(1), 1--37.

Glover, B. (2011). The Expected Cost of Default. Finance working paper, Tepper School of Business.

Korteweg, A. (2010). The net benefits to leverage. Journal of Finance, 65(6), 2137--2170.

Leland, H. (1994). Bond Prices, Yield Spreads, and Optimal Capital Structure with Default Risk. Finance working paper 240, Haas School of Business, U.C. Berkeley.

Leland, H. E. (1998). Agency costs, risk management, and capital structure. Journal of Finance, 53(4), pp. $1213--1243$.

Leland, H. E. \& Toft, K. B. (1996). Optimal capital structure, endogenous bankruptcy, and the term structure of credit spreads. Journal of Finance, 51(3), 987--1019.

Wan, E. \& Van Der Merwe, R. (2001). The Unscented Kalman Filter. In Kalman Filtering and Neural Networks chapter 7, (pp. 221--280).

Weiss, L. A. (1990). Bankruptcy resolution: Direct costs and violation of priority of claims. Journal of Financial Economics, 27(2), 285 -- 314. 


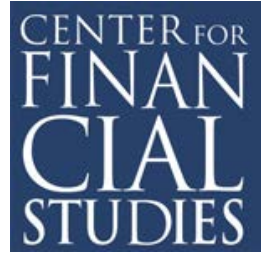

\section{CFS WORKING PAPER SERIES}

\begin{tabular}{|c|c|c|}
\hline No. & Author(s) & Title \\
\hline $2013 / 26$ & $\begin{array}{l}\text { Jaewon Choi } \\
\text { Dirk Hackbarth } \\
\text { Josef Zechner }\end{array}$ & Granularity of Corporate Debt \\
\hline $2013 / 25$ & $\begin{array}{l}\text { Giuseppe Bertola } \\
\text { Winfried Koeniger }\end{array}$ & $\begin{array}{l}\text { Hidden Insurance in a Moral Hazard } \\
\text { Economy }\end{array}$ \\
\hline $2013 / 24$ & $\begin{array}{l}\text { Rong Hai } \\
\text { Dirk Krueger } \\
\text { Andrew Postlewaite }\end{array}$ & $\begin{array}{l}\text { On the Welfare Cost of Consumption } \\
\text { Fluctuations in the Presence of Memorable } \\
\text { Goods }\end{array}$ \\
\hline $2013 / 23$ & $\begin{array}{l}\text { Jill E. Fisch } \\
\text { Tess Wilkinson-Ryan }\end{array}$ & $\begin{array}{l}\text { Why Do Retail Investors Make Costly } \\
\text { Mistakes? An Experiment on Mutual Fund } \\
\text { Choice }\end{array}$ \\
\hline $2013 / 22$ & $\begin{array}{l}\text { Christiane Baumeister } \\
\text { Pierre Guérin } \\
\text { Lutz Kilian }\end{array}$ & $\begin{array}{l}\text { Do High-Frequency Financial Data Help } \\
\text { Forecast Oil Prices? The MIDAS Touch at } \\
\text { Work }\end{array}$ \\
\hline $2013 / 21$ & Brigitte Haar & $\begin{array}{l}\text { Investor protection through model case } \\
\text { procedures - implementing collective goals } \\
\text { and individual rights under the } 2012 \\
\text { Amendment of the German Capital Markets } \\
\text { Model Case Act (KapMuG) }\end{array}$ \\
\hline $2013 / 20$ & $\begin{array}{l}\text { Nikolaus Hautsch } \\
\text { Julia Schaumburg } \\
\text { Melanie Schienle }\end{array}$ & $\begin{array}{l}\text { Financial Network Systemic Risk } \\
\text { Contributions }\end{array}$ \\
\hline $2013 / 19$ & $\begin{array}{l}\text { Taras Bodnar } \\
\text { Nikolaus Hautsch }\end{array}$ & $\begin{array}{l}\text { Copula-Based Dynamic Conditional } \\
\text { Correlation Multiplicative Error Processes }\end{array}$ \\
\hline
\end{tabular}

All CFS Working Papers can be downloaded at www.ifk-cfs.de/publications/working-papers. 